\title{
Discussion Paper No. 17-011 \\ The True Art of the Tax Deal: \\ Evidence on Aid Flows and Bilateral Double Tax Agreements
}

Julia Braun and Martin Zagler

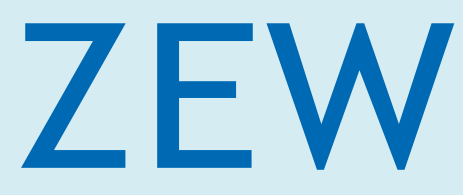

Zentrum für Europäische Wirtschaftsforschung $\mathrm{GmbH}$

Centre for European

Economic Research 


\title{
Discussion Paper No. 17-011 \\ The True Art of the Tax Deal: Evidence on Aid Flows and Bilateral Double Tax Agreements
}

\author{
Julia Braun and Martin Zagler
}

Download this ZEW Discussion Paper from our ftp server:

http://ftp.zew.de/pub/zew-docs/dp/dp17011.pdf

Die Discussion Papers dienen einer möglichst schnellen Verbreitung von neueren Forschungsarbeiten des ZEW. Die Beiträge liegen in alleiniger Verantwortung der Autoren und stellen nicht notwendigerweise die Meinung des ZEW dar.

Discussion Papers are intended to make results of ZEW research promptly available to other economists in order to encourage discussion and suggestions for revisions. The authors are solely responsible for the contents which do not necessarily represent the opinion of the ZEW. 


\title{
The true art of the tax deal: Evidence on aid flows and bilateral double tax agreements*
}

\author{
Julia Braun ${ }^{\dagger}$ and Martin Zagler
}

Version: 7.2.2017

\begin{abstract}
Out of a total of 2,976 double tax agreements (DTAs), some $60 \%$ are signed between a developing and a developed economy. As DTAs shift taxing rights from capital importing to capital exporting countries, the prior would incur a loss. We demonstrate in a theoretical model that in a deal one country does not trump the other, but that the deal must be mutually beneficial. In the case of an asymmetric DTA, this requires compensation from the capital exporting country to the capital importing country. We provide empirical evidence that such compensation is indeed paid, for instance in the form of bilateral official development assistance, which increases on average by six million US\$ in the year of the signature of a DTA.
\end{abstract}

Keywords: developing countries, foreign aid, double taxation agreements.

JEL-Codes: K33, F53, H25, H87, D82.

\footnotetext{
${ }^{*}$ The authors wish to thank Philipp Danninger, Paolo Ghinetti, Eckhard Janeba, Sunghoon Hong, Pasquale Pistone, Viktoria Wöhrer, the participants of the Destat Workshop in Cape Town, the WU Department of Economics Research Seminar, the Matax Workshop, the 6d6 Seminar in Novara and the IIPF conference for helpful comments and suggestions to earlier versions of the paper. Financial support from the Norwegian Science Fund (DeSTaT project) and the OeNB Jubiläumsfonds No. 16017 is gratefully acknowledged. The authors also gratefully acknowledge support from the MannheimTaxation (MaTax) Science Campus, funded by the Leibniz Association, the State of Baden-Württemberg, and the participating institutions ZEW and University of Mannheim.

${ }^{\dagger}$ Centre for European Economic Research (ZEW), L7,1, 68161 Mannheim, Germany and DIBT Fellow, julia.braun@zew.de

${ }^{\ddagger}$ UPO University of Eastern Piedmont and WU Vienna University of Economics and Business
} 


\section{Introduction}

With rising cross-border capital flows, the interaction of national tax jurisdictions has increasingly gained in relevance in the last decades. Given the lack of a unified global tax order and the so far limited scope of multilateral initiatives, the tax treatment of cross-border activities remains to a large degree regulated by bilateral double taxation agreements (DTAs) ${ }^{1}$ These agreements set tax rules and allocate taxing rights between the two signatory states.

Of the 2,976 DTAs in place as of 2010, some 500 DTAs covered relationships between OECD countries (17\% of the total). About a third of the treaties were signed between two developing economies, and more than $50 \%$ were between a developing on the one hand and an OECD country on the other hand Baker, 2014. This latter category, so-called asymmetric DTAs, are the focus of this paper.

The large majority of DTAs is drafted along either the OECD or the U.N. Model Tax Conventions (MTC) Wijnen and de Goede, 2014]. Both these conventions (albeit the U.N. Convention to a lesser degree) tend to shift taxing powers from the source state, i.e. the state where income is generated, to the residence state of a company. For two countries with largely symmetrical investment patterns this imbalance is not problematic.

Conversely, when two countries with an asymmetric investment position sign such a DTA, this shifting of taxing powers inherently implies a loss of tax base for the capital-importing country [see e.g. Rixen and Schwarz, 2009]. With capital still flowing predominantly from industrialized to developing countries and capital income flowing the other way, such agreements may thus put capital-importing developing countries at a disadvantage.

This raises the question as to why capital-importing countries sign such DTAs.

\footnotetext{
${ }^{1}$ A multilateral instrument for the streamlining of DTAs has recently been proposed by the OECD in the framework of the Base Erosion and Profit Shifting (BEPS) project.
} 
Several reasons have been brought forward. Most prominently, it has been argued that developing countries expect increased capital-inflows after the signature of DTAs [e.g. Lang and Owens, 2014]. Empirical evidence as to whether DTAs indeed lead to higher investment flows is, however, far from conclusive [see e.g. Baker, 2014. From a policy perspective, Pickering 2013 argues that capital exporting countries have a higher bargaining power and thus can pressure capital-importers into signing DTAs.

In this paper, we propose a further explanation. We argue that capital exporters use foreign aid to incite capital-importers into signing DTAs. We claim that capital importers that sign a DTA are compensated through official development assistance (ODA). We regard this not as an alternative but as an additional mechanism to explain the signing of DTAs between countries with unbalanced investment patterns.

The strategic use of ODA as a foreign policy instrument has been documented in various contexts. Alesina and Dollar 2000] argue that the allocation of foreign aid can - to a large extent - be explained by political and strategic factors. They find a positive association between the amounts of bilateral aid a country receives and its alignment with the respective donor country's voting behaviour at the U.N. General Assembly. Kuziemko and Werker 2006 find that U.S. and U.N. aid flows to the rotating members of the United Nations Security Council rise significantly during the two-year period of their Security Council membership. The authors argue that the patterns found are best explained through strategic vote buying. In addition, temporary members of the United Nations Security Council are found to benefit from more programs from the International Monetary Fund (and from programs with more favourable conditions) Dreher et al., 2009b. Further, Dippel 2015 provides evidence of the strategic use of ODA by major donors in order to influence or reward voting behaviour in the International Whaling Organization.

Similarly, analysing the political economy of aid in donor and recipient countries theoretically and empirically, de Mesquita and Smith 2009 conclude that 
OECD countries' bilateral giving is only to a small degree motivated by humanitarian motives. Faye and Niehaus [2012] find that in election years, donors try to actively influence election outcomes in recipient countries by disbursing additional aid to closely aligned governments. Kersting and Kilby [2016] find evidence of global electioneering that specifically serves U.S. foreign policy interests.

Empirical evidence thus illustrates that besides the humanitarian needs of recipient countries, also strategic interests of donor countries determine the allocation of foreign aid. While evidence for this quid-pro-quo view has been found in various contexts, interestingly, so far the literature has not inquired into the question as to whether ODA is used as a strategic instrument in the bargaining of bilateral treaties.

With regards to bilateral tax treaties, due to their benefits being predominantly on the side of capital-exporting countries, a number of legal and economic scholars have pleaded for the inclusion of revenue sharing mechanisms into DTAs between countries with asymmetric investment positions [e.g. Paolini et al., 2015, Thuronyi, 2010]. To our knowledge, potential connections between DTAs and existing foreign aid payments have, however, only been addressed by Braun and Zagler [2014]. In a pure cross-section study for 2010 the authors find a positive association between bilateral ODA commitments and the existence of DTAs.

The present paper contributes to the literature on the determinants of foreign aid by providing evidence that foreign aid is used strategically to put pressure on or reward recipient countries when it comes to negotiating bilateral treaties from which the donor country typically benefits more than the recipient country. We examine DTAs that are signed between donor and recipient countries between 1991 and 2012. Using a fixed effects poisson model, we find that on average, donor countries' aid commitments to the other signature state increase by about $22 \%$ in the year of signature. Evaluated at the sample mean, this translates into around six million USD additional aid commitments in a DTA signatory year. We interpret this increase in ODA as compensation for DTA signature. 
This finding is important because it shows a new dimension and a further channel in which foreign aid may be used as a strategic policy instrument. From this perspective, this paper additionally contributes to the discussion regarding the efficiency of aid, since it is heavily dependent on its allocation Faye and Niehaus, 2012 .

The paper proceeds as follows. The next section briefly discusses the institutional background of asymmetric DTAs. In Section 3, we set up a simple Nash bargaining model analyzing the supply of tax-related information as provided for in bilateral tax treaties. After describing the data and methodology in Sections 4 and 5, we empirically test the model hypothesis that bilateral foreign aid is used as a strategic instrument to reward countries for their agreeing to sign a DTA (Section 6). Section 7 presents a series of robustness checks and Section 8 concludes.

\section{Institutional Background: Asymmetric DTAs}

Foremost, DTAs serve to allocate taxing powers between signatory states in order to prevent double taxation in cross-border situations. In addition, DTAs are increasingly seen as instruments to prevent double non-taxation of international economic activities. For instance, DTAs include anti-abuse provisions and enable or facilitate the exchange of information and administrative assistance between tax authorities of the two signatory states. Overall, DTAs are signed in order to increase tax certainty for companies engaged in international business (for instance multinational enterprises) and to ensure efficient tax collection for signatory states.

Most DTAs are based on the Model Tax Conventions (MTC) proposed by the OECD and the U.N. and thus are very similar. The fact that the same underlying principles are embodied in all treaties makes them especially suitable for our analysis. This ensures that we have a large number of similar treaties from which we can generally expect similar effects and thus can treat them equally in the 
empirical analysis. $2^{2}$

How do DTAs specifically allocate taxing rights between the two signatory states? Generally, DTAs distinguish two types of income, for which different allocation rules apply: active business income and passive income. Active business income simply means business profits. The primary right to tax is with the residence country. Only when a (multinational) company has a substantial business presence (e.g. a fixed place of business) - a so-called permanent establishment $(\mathrm{PE})$ - in the other state, then the other state has the right to tax the profits attributable to the PE (Article 7 OECD MTC). The residence country is then obliged to prevent double taxation by applying the exemption or credit method as provided for in Article 23 of the OECD MTC.

Thus, the definition of a PE and the method of defining the income to be allocated to a PE decide on which state is allowed to tax the respective income. The OECD MTC (and the UN MTC, albeit to a lesser extent) generally shifts taxing powers from the source to the residence country by defining both a PE and the income attributable to the PE more narrowly than many national legislations - especially in developing countries [see e.g. Braun and Fuentes, 2016].

When it comes to passive income, i.e. dividends, royalties, and interest payments, the residence country has the primary right to tax, and the source country is granted the right to levy limited withholding tax rates on these types of income (see Articles 10, 11, and 12 of the OECD MTC). Typically, DTAs provide

\footnotetext{
${ }^{2}$ This should, however, not conceal that DTAs are the outcome of bilateral negotiations. This concerns not only the decision as of whether or not two states enter into a DTA, but also the propositions of the individual articles. Analysing U.S. and German DTAs respectively, Chisik and Davies 2004 and Rixen and Schwarz 2009 find that these two countries agree on higher withholding tax rates in DTAs when investment positions are more asymmetric. Rixen and Schwarz 2009 also find that the definition of permanent establishments is generally broader in asymmetric treaties. These two findings imply that, in comparison with DTAs between countries with more symmetric investment patterns, asymmetric treaties leave more taxing power with the source country. Source countries thus seem to have some bargaining power. At the same time, the pervasiveness of specific UN Model provisions in DTAs is found to be surprisingly small. In a comprehensive overview study, Wijnen and de Goede 2014] find that 21 of the specific provisions proposed by the UN MTC are included in less than $40 \%$ of the DTAs concluded between 1997 and 2012.
} 
for a reduction of withholding tax rates in the source state, which implies "a revenue transfer from the net capital importer to the net capital exporter" Rixen and Schwarz, 2009, p. 446]. Analysing a sample of 18 European countries' DTAs with developing countries, Eurodad 2016] finds that the withholding tax rates on dividends, royalties, and interest stipulated in these DTAs are on average $3.8 \%$ lower than the respective rates in domestic laws ${ }^{3}$

A number of case studies discusses such problematic features inherent in DTAs in great detail and attempts to quantify their impact on developing countries $4^{4}$ Asymmetric DTAs, i.e. DTAs signed between capital-exporters and capital-importers, which are based on OECD MTC (and to a lesser degree also the ones based on the UN MTC) thus imply inherent downsides for capital-importing countries by limiting their taxing powers [see e.g. Dagan, 2000, Daurer, 2013, Rixen and Schwarz, 2009.

Due to rapidly growing interdependencies between economies, the exchange of information has gained more and more importance for respective tax authorities. Particularly multinationals' cross-border activities raise the awareness, since the majority of national tax systems are residence-based. Furthermore, individual source taxation rates have declined over recent years. Therefore the monitoring of taxpayers' international activities, followed by a correct assessment of tax liabilities is crucial.

While the tax authorities of capital-exporting economies typically have a greater interest in receiving tax-related information, also net capital importing countries benefit from the exchange of information in tax matters. Tax authorities from low-income countries are often interested in requesting information regarding the capital of their high net worth individuals parked abroad. Additionally, firms resident in developing countries are increasingly becoming international. Outward

\footnotetext{
$\sqrt[3]{\text { Eurodad } 2016, \text { p. 23]. }}$

${ }^{4}$ see e.g. Braun and Fuentes 2016 for a case study on Austria's DTA network with developing countries, McGauran [2013] for a case study on the Netherlands' tax treaties with developing countries, and Buergi and Meyer-Nandi 2013] for an analysis of Swiss tax treaties with developing countries, ActionAid [2014] for a survey of Uganda's DTAs.
} 
foreign direct investment (FDI) flows from developing and transition economies have been increasing, and in 2015 made up $27.7 \%$ of global FDI outflows. However, in the same year, the combined outward FDI stocks from developing and transition countries only amounted to $22.4 \%$ of worldwide outward FDI stocks. 5

In the majority of cases, the (net) information flow mainly flows from the low-income country to the high-income country 6 Given that retrieving and providing such information is costly, the increased demand for information may thus aggravate the structural disadvantages arising from DTAs for capital-importing countries. The next section formally illustrates the implicit disadvantage in DTAs and why compensation is expected in case of a voluntary signature of a DTA between two countries with an asymmetric investment position.

\section{The model}

If a resident (corporation) in one country (country $R$ henceforth) pursues economic activities in another country (country $S$ to indicate the source of income) that are liable to taxation in its country of residence, this country requires information on the tax base and the amount of taxes due. There are several ways to obtain this information. First, the tax authority can ask the tax subject herself. For obvious reasons, $7^{7}$ the tax authority may not receive the correct reply. As opposed to economic activity in its own territory, the tax authority in country $R$ cannot investigate abroad due to a lack of jurisdiction. However, it can ask the tax authorities

\footnotetext{
${ }^{5}$ UNCTAD, FDI/MNE database www . unctad.org/fdistatistics

${ }^{6}$ There is only very limited data available on the bilateral information flows between tax authorities. The Peer Review Reports published by the Global Forum on Transparency and Exchange of Information for Tax Purposes reveal the respective numbers only for very few nonOECD countries. For instance, the OECD Peer Review Report for Malaysia shows that the country received 61 requests of information between 2010 and 2012 and sent only one request during the same time period OECD, 2014, p. 105 and 134]. The Philippines received 67 requests of information regarding direct taxation between 2009 and 2012, while they sent only two requests to other tax authorities in the same years OECD, 2013, p. 101].

${ }^{7}$ By understating the tax base, the subject would reduce her tax burden without a possibility for the authorities to check the validity of the statement.
} 
abroad to assist in verifying the information of its tax subject. Country $S$ may be reluctant to supply this type of information, due to direct and indirect costs. Direct costs obviously include information collection and audit costs. Indirect costs are effects that impact country $S$, as agents will require excess withholding taxes back as a next step, or move their business to a third country, thus withdrawing tax base and foreign direct investment from country $S$, leading to repercussions on GDP and employment. Country $S$ will therefore supply very little information to other jurisdictions. In order to circumvent this difficulty, an incentive compatible contract can be signed between the two countries $R$ and $S$.

We assume that country $R$ can tax foreign income with a constant average tax rate $\tau$, so that every unit of tax base information $q$ has the same value to country $R$. We can think of $\tau$ as the reservation price above which country $R$ would no longer be willing to purchase information. Country $S$, by contrast, has different costs of information procurement, starting at nothing (in case the information is readily available, and decreasing in the size of the economic activity (the larger the economic activity the easier it should be per unit), and the complexity of the underlying business activity. We will rank information according to their procurement cost for country $S$, from the cheapest to the most costly 8 according to the following cost function,

$$
C=c(q)
$$

with $c(q) \geq 0, d c / d q=\dot{c}(q) \geq 0$. We define average costs as $C / q=c(q) / q=a(q)$. There is a rent of information sharing (and hence the possibility of a mutually beneficial deal) if and only if the maximum willingness to pay of country $R$ exceeds the marginal cost of procurement of country $S$,

$$
\dot{c}(q) \leq \tau
$$

Suppose for a moment that information could be provided and demanded by many

\footnotetext{
${ }^{8}$ For the sake of simplicity, we assume full divisibility of information.
} 
different agents. This would lead to perfect competition in a market for information, and information would be exchanged until equation (2) is satisfied with equality, and, due to perfectly elastic demand, the price for information would be equal to the gain for country $R$ from the information, $p^{p c}=\tau$. This is the exact opposite of the current practice in DTAs, where information may be shared free of charge, $p^{d t a}=0$. Note that in the latter case, Country $S$ would willingly share only information that comes at no cost, and this may be the reason for the low number of information exchanges registered empirically.

We are, however, not in a situation of perfect competition. As a specific piece of tax information is only available to country $S$, and only useful to country $R$, the two governments would need to negotiate over that piece of information. We will therefore use Nash bargaining to solve for the price at which information would be voluntarily shared by country $S$ and voluntarily purchased by country $R$. We can define the surplus for country $R$ as the difference between the gain from information, $\tau q$, minus the price paid for that information, $p q$,

$$
U_{R}=(\tau-p) q
$$

Similarly, the surplus for country $S$ is equal to the revenue from selling information, $p q$, minus the cost of information procurement, $C$,

$$
U_{S}=p q-c(q)
$$

This defines a bargaining problem Rubinstein, 1982, where upon agreement a quantity of information $q$ is exchanged at price $p$ leading to the surpluses $U_{R}$ and $U_{S}$ as defined above, whereas under disagreement no information is exchanged, $q=0$. Defining the bargaining power of country $R$ with $0 \leq \beta \leq 1$, the Nash maximand reads,

$$
N=\left(U_{R}\right)^{\beta}\left(U_{S}\right)^{1-\beta}=(\tau-p)^{\beta} q^{\beta}[p q-c(q)]^{1-\beta}
$$


where both $U_{R}$ and $U_{S}$ must be positive, or $a(q) \leq p \leq \tau$. Taking the first order condition with respect to the price $p$ gives,

$$
-\beta(\tau-p)^{\beta-1} q^{\beta}[p q-c(q)]^{1-\beta}+(1-\beta)(\tau-p)^{\beta} q^{\beta+1}[p q-c(q)]^{-\beta}=0
$$

Upon rearranging, we find the bargaining price,

$$
p=\beta a(q)+(1-\beta) \tau
$$

It turns out that the result is a weighted average between the reservation price of country $R, \tau$, and the average cost of providing this information, $a\left(q^{*}\right)$, for country $S$. The price will equal the reservation price of country $R, p=\tau$ if its bargaining power is null, $\beta=0$. In this case country $S$ can extract all rents for itself. The price will equal average costs of country $S$ if its bargaining power is null, $\beta \rightarrow 1$. In this case country $R$ can extract all rents for itself.

The price will be null if and only if average costs are zero and the bargaining power $\beta$ equals unity. Coincidentally, this is the current legal situation in Tax Information Exchange Agreements and Double Tax Treaties with provisions for the exchange of information. Whilst this may not pose a problem in situations where both countries posses a similar amount of information? when the countries are asymmetric, with one country the predominant provider of information and the other country the predominant receiver, the above model predicts little to no information to be exchanged, if average costs of acquiring information are nonnegligible, as argued above. This asymmetric situation is typical for developing countries, which are capital importers and therefore should be able to retrieve information requested by the capital exporting developed country. We therefore suggest that TIEAs and DTAs should include cost ${ }^{10}$ and revenue sharing to succeed

\footnotetext{
${ }^{9}$ In two separate bargaining problems, neither country would be willing to provide information that comes at a cost, but in a joint bargaining problem, our educated guess is that information will be exchanged voluntarily.

${ }^{10}$ As mentioned above, costs are opportunity costs and include both direct and indirect costs.
} 
in retrieving information.

Maximizing equation (5) with respect to the amount of information exchanged $q$ yields,

$$
\beta(\tau-p)^{\beta} q^{\beta-1}[p q-c(q)]^{1-\beta}+(1-\beta)(\tau-p)^{\beta} q^{\beta}[p q-c(q)]^{-\beta}[p-\dot{c}(q)]=0
$$

Simplifying and rearranging yields,

$$
p=\beta a(q)+(1-\beta) \dot{c}(q)
$$

which differs from the bargaining outcome (6) only in the last term. From equations (6) and (7) we can conclude that the quantity of information exchanged in a Nash bargaining is therefore given by $\dot{c}\left(q^{*}\right)=\tau$, and is equivalent to the amount of information exchanged under perfect competition (2). Nash bargaining therefore does not distort the optimal amount of information exchanged. We can infer the quantity of information exchanged by invoking the inverse of equation (2),

$$
q^{*}=\dot{c}^{-1}(\tau)
$$

Figure 1 illustrates the argument. We have depicted the reservation price of country $R$ as a horizontal green line. We have also drawn the marginal cost curve of country $S$ as an upward sloping red line. At the intersection of these two curves, point $B$, we identify the quantity of information exchanged in the bargaining model. Finally, we have drawn three different average cost curves of country $R$, which differ only in the amount of fixed costs. $a_{2}(q)$ has a minimum above the reservation price, and hence there exists no solution where information is exchanged.

The average cost curve $a_{1}(q)$ has its minimum below the reservation price, and therefore permits the exchange of information.11 The minimum amount at which

\footnotetext{
${ }^{11}$ Bargaining will not lead to the maximum amount of information exchanged, which would
} 
Figure 1: Nash Bargaining over Information Exchange

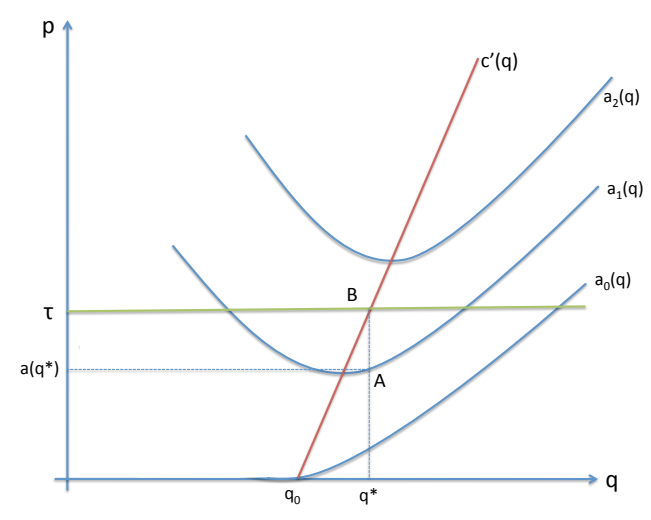

country $S$ is willing to sell information is indicated by point $A$. The difference between $A$ and $B$ indicates the total economic rent that can be gained from bargaining. The division of this rent depends on relative bargaining power. If country $S$ has all the bargaining power, $\beta=0$, according to equation (6), the exchange would happen in point $B$. If country $R$ has all the bargaining power, $\beta \rightarrow 1$, the price would be set at point $A$. In both cases, the price exceeds zero.

The only possibility to have exchange of information at zero cost is depicted by average cost $a_{0}(q)$, where fixed costs and marginal costs below a certain threshold $q_{0}$ are null ${ }^{12}$ Here, if country $R$ has all the bargaining power, the bargaining outcome would be a corner solution, and a quantity $q_{0}$ of information would be exchanged at a prize $p=0$. In this case, information exchange is inefficient, as country $R$ would be willing to pay for additional information and country $S$ would be willing to provide additional information at that price.

We have thus established that in an asymmetric DTA, there should be a compensation for country $R$ by country $S$. We can identify the amount of compensation

be where the average cost curve $a_{1}(q)$ intersects the reservation price $\tau$. Instead, information is exchanged at a lower level, as additional cost for providing information exceeds the willingness to pay. Information exchange in a bargaining model is therefore efficient.

${ }^{12}$ This case is hypothetical, as costs of acquiring information are typically non negligible. 
paid simply by multiplying price with quantity and substituting equation(6),

$$
p q^{*}=\beta c\left(q^{*}\right)+(1-\beta) \tau q^{*}
$$

In the following section, we aim to find evidence in support of this theory of compensation. Whilst there is no DTA that explicitly includes compensation, we test whether there is implicit compensation in place. Compensation may come in many forms. One possibility can be foreign aid paid by the information receiving country to the information provider. We will therefore look at official development assistance (ODA) as an - albeit imperfect - measure of compensation for signing a treaty.

Compensation depends on three elements: the optimal quantity of information exchanged, bargaining power, and the reservation price, given by the tax rate in the country of residence $R$. An increase in the amount of information exchanged itself depends on several factors as indicated above (8), but ceteris paribus we can ascertain that,

$$
\frac{\partial p q^{*}}{\partial q^{*}}=\beta \dot{c}\left(q^{*}\right)+(1-\beta) \tau=\tau>0
$$

We may imagine that the stronger the economic relation between two countries as measured by trade or FDI flows is, the larger will be the amount of compensation. It is straightforward to see that an increase in the bargaining power of country $R$ reduces the amount of compensation,

$$
\frac{\partial p q^{*}}{\partial \beta}=c\left(q^{*}\right)-\tau q^{*}<0
$$

Bargaining power can be approximated by the size of a country (population or GDP) ${ }^{13}$

Finally, an increase in the reservation price of country $R$ has an impact on compensation both directly and indirectly by altering the quantity of information

\footnotetext{
${ }^{13}$ Or the presence of a Donald Trump in the negotiation team. We will use country fixed effects to control for the latter.
} 
exchanged,

$$
\frac{\partial p q^{*}}{\partial \tau}=(1-\beta) q^{*}+\frac{\tau}{\ddot{c}\left(q^{*}\right)}
$$

where $\ddot{c}\left(q^{*}\right)$ is the second derivative of the cost function and ambiguous of sign, so that we cannot draw any conclusions on the impact of the residence country's reservation price on the amount of compensation.

\section{Data}

We construct a dyadic panel dataset that consists of country-pairs with an ODA donor country on the one hand and an ODA recipient country on the other hand. The analysis covers the period 1991 to 2012 . The list of donors includes the 23 states that were DAC (Development Assistance Committee) members as of 2012 (see Table 3 in the Annex). Apart from Greece, that joined the DAC in 1999, and the Republic of Korea, that joined in 2010, all other countries were members during the entire sample period 114 The recipient countries comprise of the countries included in the 2012 DAC list of potential ODA recipients, which encompasses low and middle income countries according to the 2012 World Bank income classification. We use bilateral foreign aid commitments as our dependent variable. Information on ODA commitments has been sourced from the OECD DAC database.

As we are interested in the question as to whether ODA is used by donor countries to compensate potential recipient countries when signing a DTA, our main variable of interest concerns DTAs. Information on DTA signatures is taken from the IBFD Tax Research Platform. Between 1991 and 2012, 372 DTAs were signed between 23 donor and 75 recipient countries. 24 of these DTAs are not included in the empirical analysis because there are no aid commitments within these country-pairs in the years analysed. The final sample used in the regression

\footnotetext{
${ }^{14}$ Table 9 shows regressions results excluding these two countries as donor countries. The results remain unchanged.
} 
Figure 2: DTA signatures 1991-2012

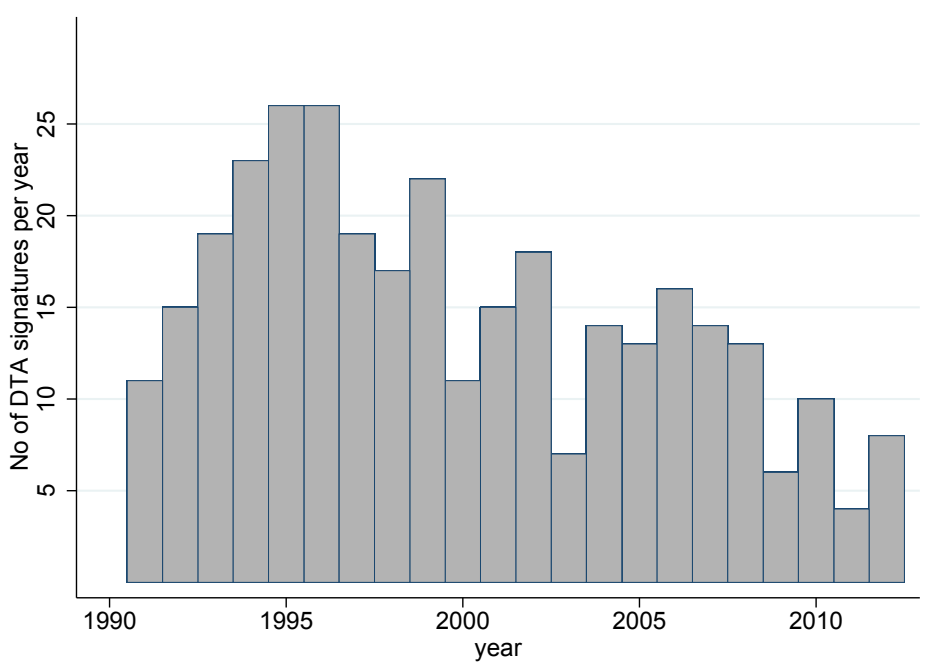

Datasource: IBFD Taxation Platform, own illustration

analysis, which is further reduced due to missing data in the covariates, includes 327 DTA signatures between 21 donor countries and 69 recipient countries.

Figure 2 shows the distribution of these DTA signatures over the sample period. The number of yearly DTA signatures ranges between four in 2011 and 27 in 1995 and 1996. On average, 14.8 DTAs were signed each year, with a higher average number of yearly signatures in the 1990s than in the following years.

The analysis includes all DAC donor countries as of 2012 with the exception of Ireland and Portugal (see Figure 3). These two countries signed DTAs but did not commit to any aid to the other signatory states during the sample period. During the 22 years covered by the analysis, each donor country signed on average 15.6 DTAs. The number of new DTAs per donor country varies between three (New Zealand) and 27 new treaties (Switzerland).

The majority of the recipient countries are middle income countries. 170 DTAs with upper middle income countries, and 131 with lower middle income countries, and only 26 DTAs with low income countries are covered by the analysis. Table 4 
Figure 3: DTA signatures per donor country 1991-2012

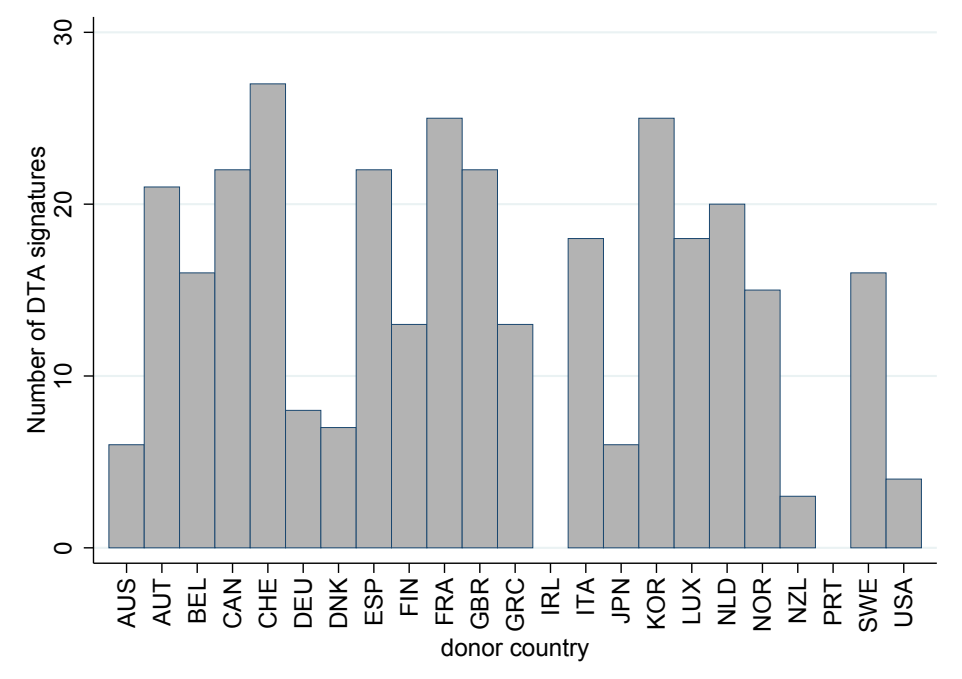

Datasource: IBFD Taxation Platform, own illustration

in the Annex presents a complete list of recipient countries with their respective number of treaties concluded between 1991 and 2012 that are included in the analysis.

Geographically, the main area covered is Europe and Central Asia (104 of the analysed DTAs), followed by Asia \& Pacific (77 DTAs) and Sub Saharan Africa (59 DTAs). In addition, the analysis includes 50 DTAs with Latin America and the Caribbean and 37 DTAs with countries in the Middle East and North Africa.

The explanatory variable of interest is a binary variable, taking the value of one if a country-pair signs a DTA in a particular year and is otherwise zero. We will include leads and lags of this variable to ensure that the relationship is not coincidental. We will also compare the results with a level dummy of DTAs that jumps from zero to unity onwards from the year the DTA is signed. We further include other international treaties, such as preferential trade agreements and bilateral investment treaties. Finally, we include the factors which are generally found to matter for donors when allocating foreign aid: population, poverty, proximity, and 
policies Clist, 2011].

\section{$5 \quad$ Methodology}

We question as to whether ODA is used by donor countries to compensate potential recipient countries when signing a DTA. To analyse this hypothesis, we use bilateral foreign aid commitments as our dependent variable. Information on ODA commitments comes from the OECD DAC database. The typical distribution of bilateral aid with the large number of zero observations poses a challenge for regression analysis. Log-linearized gravity-type OLS models with fixed effects are not the most suitable models for this kind of data. Not only do these models require an arbitrary adjustment of the dependent variable, but, in the presence of heteroskedasticity, the estimates are inconsistent, and their interpretation can be misleading, even when robust standard errors are applied Silva and Tenreyro, 2006 .

Instead, Silva and Tenreyro 2006 suggest the use of fixed effect poisson models (FEPM). These models explicitly take the non-linearity of the dependent variable into account, are robust to heteroskedasticity, and control for unobserved heterogeneity. Moreover, in FEPM, the dependent variable does not need to follow a Poisson distribution, nor does it need to be an integer number. For the estimator to be consistent, only the correct specification of the conditional mean is required. In addition, and very importantly in our case, the FEPM also performs well under a large number of zero observations in the dependent variable. Besides, the parameter estimates can be directly interpreted as elasticities Silva and Tenreyro, 2006, 2011.

As bilateral trade shows a similar data structure of (excess) zeros in the dependent variable and the presence of heteroskedasticity in constant elasticity models, the international trade literature has widely used FEPM models Silva and Ten- 
reyro, 2006 .15 Using a FEPM, we therefore analyse the connection between ODA commitments and the signature of a DTA. The regression model, which is estimated using the maximum likelihood method, takes the following form:

$$
O D A_{i j t}=\exp \left(\alpha_{i j}+\beta * D T A_{i j t}+\gamma * X_{i j t-1}+\theta_{i j}+\eta_{t}\right)+\varepsilon_{i j t}
$$

Total bilateral ODA commitments (in constant USD) are the dependent variable. The explanatory variable of interest is $D T A_{i j t}$, a binary variable taking the value of one if a country-pair $i j$ signs a DTA in year $t$. Additional control variables $\left(X_{i j t-1}\right)$ are lagged by one period. Country-pair fixed effects $\left(\theta_{i j}\right)$, year-fixed effects $\left(\eta_{t}\right)$, and a constant $\alpha_{i j}$ are included, and $\varepsilon_{i j t}$ stands for the error term.

\section{Empirical evidence}

Column (1) in Table 1 includes all 2,434 country-pairs for which we have collected data. Besides including a DTA dummy variable, we account for the factors which are generally found to matter for donors when allocating foreign aid: population, poverty, proximity, and policies Clist, 2011] ${ }^{16}$ We will now describe these control

\footnotetext{
${ }^{15}$ Even though the aid literature mostly uses OLS regression models, there are exceptions. Kersting and Kilby [2016], for instance, employ OLS and Tobit regressions with logged ODA commitments as the dependent variable. However, consistent Tobit estimation relies on strong assumptions, including (i) a normally distributed and homoskedastic error term, (ii) explanatory variables affecting the dependent variable equally along the extensive and intensive margin, and (iii) due to the incidental parameters problem a FE estimation of the Tobit model is not feasible Bittschi et al. 2016]). Another strategy in order to keep the zero observations is followed by Dippel [2015]. Instead of logged ODA values, he uses the absolute ODA values as a dependent variable. de Mesquita and Smith 2009] use a logit model to analyse the binary question as of whether or not aid is given to a specific country. Barthel also uses a two-part model with a first stage random effects probit model and a second stage with OLS estimations. Studying a slightly different question, namely which factors determine whether aid is given directly to the recipient country's government or whether it is given to non-state actors in the recipient country, Dietrich 2013 uses probit and poisson regressions.

${ }^{10}$ Complete descriptive statistics are depicted in Table 6 in the Annex and the sources of the data are depicted in Table 7 in the Annex.
} 
Table 1: Baseline Regression Results

\begin{tabular}{|c|c|c|c|c|c|}
\hline VARIABLES & $(1)$ & $\overline{(2)}$ & $(3)$ & $(4)$ & $(5)$ \\
\hline POP_donor(ln) & $\begin{array}{c}3.384^{* *} \\
(1.717)\end{array}$ & $\begin{array}{l}5.040^{* *} \\
(2.075)\end{array}$ & $\begin{array}{c}5.047^{* *} \\
(2.092)\end{array}$ & $\begin{array}{c}5.070^{* *} \\
(2.098)\end{array}$ & $\begin{array}{l}5.311^{* *} \\
(2.133)\end{array}$ \\
\hline POP_recipient(ln) & $\begin{array}{c}0.954^{* *} \\
(0.426)\end{array}$ & $\begin{array}{c}0.190 \\
(0.743)\end{array}$ & $\begin{array}{c}0.172 \\
(0.734)\end{array}$ & $\begin{array}{c}0.177 \\
(0.732)\end{array}$ & $\begin{array}{c}0.127 \\
(0.750)\end{array}$ \\
\hline GDPPC_recipient(ln) & $\begin{array}{l}-0.122 \\
(0.170)\end{array}$ & $\begin{array}{c}0.229 \\
(0.262)\end{array}$ & $\begin{array}{c}0.231 \\
(0.262)\end{array}$ & $\begin{array}{c}0.233 \\
(0.261)\end{array}$ & $\begin{array}{c}0.249 \\
(0.261)\end{array}$ \\
\hline Bilateral trade $(\ln )$ & $\begin{array}{c}-0.005^{* *} \\
(0.002)\end{array}$ & $\begin{array}{l}-0.005 \\
(0.004)\end{array}$ & $\begin{array}{l}-0.005 \\
(0.004)\end{array}$ & $\begin{array}{l}-0.005 \\
(0.004)\end{array}$ & $\begin{array}{l}-0.004 \\
(0.004)\end{array}$ \\
\hline Democracy_freedom & $\begin{array}{c}0.050^{* *} \\
(0.020)\end{array}$ & $\begin{array}{c}0.029 \\
(0.023)\end{array}$ & $\begin{array}{c}0.030 \\
(0.023)\end{array}$ & $\begin{array}{c}0.029 \\
(0.023)\end{array}$ & $\begin{array}{c}0.027 \\
(0.024)\end{array}$ \\
\hline Investment treaty & $\begin{array}{l}0.080 \\
(0.088)\end{array}$ & $\begin{array}{c}0.286^{* *} \\
(0.125)\end{array}$ & $\begin{array}{c}0.278^{* *} \\
(0.123)\end{array}$ & $\begin{array}{c}0.278^{* *} \\
(0.122)\end{array}$ & $\begin{array}{c}0.304^{* *} \\
(0.125)\end{array}$ \\
\hline Trade agreement & $\begin{array}{l}-0.096 \\
(0.115)\end{array}$ & $\begin{array}{c}0.005 \\
(0.201)\end{array}$ & $\begin{array}{c}0.005 \\
(0.202)\end{array}$ & $\begin{array}{c}0.008 \\
(0.203)\end{array}$ & $\begin{array}{l}-0.011 \\
(0.206)\end{array}$ \\
\hline DTA & $\begin{array}{c}0.210 \\
(0.128)\end{array}$ & $\begin{array}{c}0.003 \\
(0.100)\end{array}$ & & & \\
\hline $\operatorname{DTA}(-3)$ & & & & $\begin{array}{c}0.024 \\
(0.140)\end{array}$ & $\begin{array}{c}0.020 \\
(0.145)\end{array}$ \\
\hline $\operatorname{DTA}(-2)$ & & & & $\begin{array}{l}-0.138 \\
(0.146)\end{array}$ & $\begin{array}{l}-0.132 \\
(0.147)\end{array}$ \\
\hline $\operatorname{DTA}(-1)$ & & & & $\begin{array}{l}-0.032 \\
(0.124)\end{array}$ & $\begin{array}{l}-0.030 \\
(0.128)\end{array}$ \\
\hline $\operatorname{DTA}(0)$ & & & $\begin{array}{c}0.215^{* *} \\
(0.087)\end{array}$ & $\begin{array}{c}0.219^{* *} \\
(0.092)\end{array}$ & $\begin{array}{c}0.207^{* *} \\
(0.093)\end{array}$ \\
\hline $\operatorname{DTA}(+1)$ & & & & $\begin{array}{c}0.063 \\
(0.120)\end{array}$ & $\begin{array}{c}0.067 \\
(0.122)\end{array}$ \\
\hline $\operatorname{DTA}(+2)$ & & & & $\begin{array}{c}0.026 \\
(0.074)\end{array}$ & $\begin{array}{c}0.015 \\
(0.076)\end{array}$ \\
\hline $\operatorname{DTA}(+3)$ & & & & $\begin{array}{c}0.131 \\
(0.089)\end{array}$ & $\begin{array}{c}0.125 \\
(0.091)\end{array}$ \\
\hline Observations & 51,332 & 7,006 & 7,006 & 7,006 & 6,598 \\
\hline Number of groups & 2,434 & 327 & 327 & 327 & 308 \\
\hline Wald chi2 & 218.27 & 202.82 & 206.90 & 244.84 & 256.37 \\
\hline $\mathrm{p}$-value & 0.000 & 0.000 & 0.000 & 0.000 & 0.000 \\
\hline Pseudo Log-likelihood & $-540,742.47$ & $-72,846.18$ & $-72,658.12$ & $-72,516.80$ & $-69,452.28$ \\
\hline
\end{tabular}

Notes: Estimated with Poisson Maximum Likelihood Fixed Effects. The dependent variable is total bilateral ODA commitments; all explanatory variables are lagged by one period; all regressions include country-pair FE, year FE, and a constant; robust standard errors in parentheses; time period $1991-2012{ }^{* * *} \mathrm{p}<0.01,{ }^{* *} \mathrm{p}<0.05,{ }^{*} \mathrm{p}<0.1$. 
variables.

First, as a measure of country size, we include the (logged) populations of the donor and recipient countries (POP_donor $(\ln )$ and POP_recipient $(\ln ))$. Both variables are positive and significant, implying that, on average and ceteris paribus, larger countries give more aid, and larger countries also receive more aid.

Second, to proxy poverty and the needs of the recipient countries, their respective (logged) levels of GDP per capita (in constant USD) are included in the analysis $\left(G D P P C \_r e c i p i e n t(\ln )\right)$. The estimation results suggest that poverty is not a statistically significant determinant of foreign aid - at least for our sample of country-pairs and the time period analysed.

Third, traditional measures of proximity such as distance between the two signatory states, a common colonial history or a common official language are captured by the country-pair fixed effects in our estimations. Additionally, we specifically account for economic ties between the two signatory states by adding the relative volume of bilateral trade to measure the "economic distance" between two countries: $\ln ($ trade $/ g d p)$. Bilateral trade is measured as the sum of imports of country $i$ from country $j$ plus the imports of country $j$ from country $i$ in year $t$ (in constant USD). The absolute volume is then scaled by the sum of the GDPs of both countries (also measured in constant USD). This variable turns out to be negative, but statistically insignificant in most regressions.

Forth, when deciding to which countries to allocate how much aid, also recipient countries' policies have been found to matter for donors. The variable Democracy represents the combined score of the civil liberty and political rights indicators as provided by the Freedom House. Inverted scores have been used to make the interpretation more intuitive, i.e. higher scores stand for more democratic regimes. The variable is positive and significant, meaning that countries with higher levels of democracy tend to receive more foreign aid.

Finally, we include three distinct international treaty dummies, for bilateral investment treaties, preferential trade agreements and double tax agreements $(D T A)$, 
which each switch from zero to one starting in the year in which a respective treaty is signed, in order to ensure that the effect of the DTA is not confounded with the effects of other international treaties. All of these variables turn out to be statistically insignificant. As preferential trade agreements are typically multilateral agreements, bilateral compensation as proxied by an increase in bilateral aid is unlikely to be expected. With respect to DTAs and investment treaties, given that these treaties are typically very persistent (there are only few instances of treaties being terminated), a long-term effect on the level of ODA after their signature (as measured by these dummy variables) does not seem very likely. Rather, a temporary effect around the signatory date seems more plausible if this increase is to be interpreted as a compensation. Thus, as we are ultimately interested in the connection between DTA signatures and foreign aid, we restrict our sample to those country-pairs that have signed a DTA during the sample period from 1991 to 2012 in Column (2) 17

Column (2) shows the results when we restrict the sample to country-pairs that have signed a DTA during the sample period. Aid recipient characteristics turn out to be irrelevant, as population (of the recipient), poverty, proximity (trade) and policy turn insignificant. By contrast, ODA is used as a policy instrument by donor countries that seem to value political commitment - as is expressed through the positive coefficient on Investment treaty. In addition, in Column (3) we include $D T A(0)$, which is a dummy variable that is 1 only in the year where a DTA is signed and zero otherwise. This variable is positive and statistically significant, meaning that in the year a developing country signs a DTA with a DAC donor country, the developing country receives $21.5 \%$ more aid from that specific donor country. We thus have a clear indication of compensation for signing a DTA.

This compensation may however not only be given in the year a DTA is signed,

\footnotetext{
${ }^{17}$ We have looked at investment treaties, preferential trade agreements and DTA in this setting. However, for investment treaties and trade agreements the results are inconclusive. This is not very surprising, as investment treaties and trade agreements may benefit host countries just as much or more as residence countries, so it is unclear whether and in which direction compensation should flow.
} 
but may work as a means of pressure or incentive during the negotiation phase or as a reward in the years after the agreement. We therefore look at bilateral aid commitments three years before and after the signature of each DTA. Six years seem to be a good time frame as it typically takes a few years from the start of the negotiations to the actual entry into force of a DTA ${ }^{18}$ To analyse the dynamic effects of the signing of a DTA, we include the DTA variable and its three leads and lags in the regression:

$$
O D A_{i j t}=\exp \left(\alpha_{i j}+\sum_{-3}^{+3}\left(\beta_{k} D T A_{i j(t+k)}\right)+\gamma * X_{i j t-1}+\theta_{i j}+\eta_{t}\right)+\varepsilon_{i j t}
$$

Column (4) of Table 1 shows the results, and Figure 4 depicts the coefficients of the DTA variable and its leads and lags. Bilateral aid commitments tend to be lower during the three years prior to the signature of a DTA (this effect is however not statistically significant at conventional levels). Donor countries seem to hold back (or reduce) bilateral aid commitments, possibly to put pressure on the recipient country to sign the treaty.

In the signatory year, the recipient country is compensated by an increase in bilateral ODA commitments by $22 \%$. This effect is similar in size and consistently significant in all specifications. Evaluated at the sample mean, this corresponds to around six million USD of bilateral aid commitments that can on average be attributed to a DTA signature. Over all 327 DTAs signed during the sample period, this adds up to roughly 2 billion USD.

As capital-exporting countries disproportionately benefit from DTAs, our conclusions rely on the argument that donor countries typically are capital-exporting countries and recipient countries are capital-importing countries. Looking at bilateral average investment stocks over the sample period from the perspective of

\footnotetext{
${ }^{18}$ Based on a random sample of 30 country-pairs, Ligthart et al. 2012] calculate that on average 2.3 years lie between the ratification and implementation of a DTA.
} 
Figure 4: DTA signature and bilateral ODA

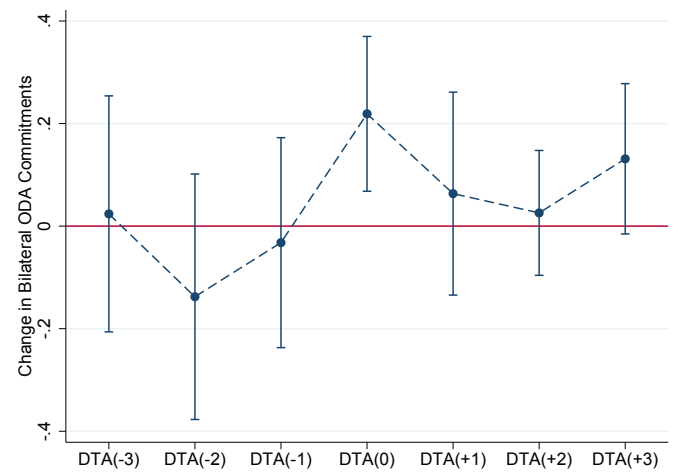

Plotted coefficients of the DTA signature indicator variable $(\mathrm{DTA}(0))$ and its three leads and lags with $95 \%$ confidence intervals (corresponding to Column 4 in Table 1 ).

the donor country, the outward FDI stocks exceeded the inward stocks for 223 country-pairs, corresponding to $68.2 \%$ of our sample. For $25 \%$ of the sample, or 85 country-pairs, the average net investment positions were zero, and in only 19 cases the average inward stocks were higher than the outward stocks (5.8\%) ${ }^{19}$ In column (5) of Table 1, we thus delete from the sample the 19 country-pairs for which the donor country's outward FDI stocks are inferior to its inward stocks (on average over the sample period). The result remains unchanged. These 19 country-pairs thus seem not to affect the results.

Our model in Section 3 has generated three testable hypotheses on an increase in foreign aid around the signature of a DTA, equations (10) to 12 . We can therefore empirically test the model predictions regarding the role of (i) the strength of economic ties, (ii) the relative bargaining power of the two countries, and (iii) the residence country's reservation price, i.e. its corporate tax rate.

The first hypothesis derived from the model is that stronger economic ties increase compensation (see Columns (1) and (4) of Table 2). Economic ties be-

\footnotetext{
${ }^{19}$ Data on bilateral FDI stocks are taken from the OECD FDI database and are calculated as outward FDI stocks from donor country $i$ in recipient country $j$ plus inward FDI stocks in donor country $i$ from recipient country $j$, both as reported by donor country $i$.
} 
Table 2: Testing Model Hypotheses

\begin{tabular}{|c|c|c|c|c|c|c|}
\hline VARIABLES & (1) & $(2)$ & (3) & (4) & $(5)$ & (6) \\
\hline POP_donor $(\ln )$ & $\begin{array}{c}5.180^{* *} \\
(2.085)\end{array}$ & $\begin{array}{c}1.060 \\
(2.489)\end{array}$ & $\begin{array}{c}4.706^{* *} \\
(2.268)\end{array}$ & & & \\
\hline POP_recipient(ln) & $\begin{array}{c}0.179 \\
(0.731)\end{array}$ & $\begin{array}{c}2.423^{* *} \\
(1.067)\end{array}$ & $\begin{array}{c}0.164 \\
(0.740)\end{array}$ & & & \\
\hline GDP_donor(ln) & & & & $\begin{array}{c}2.568^{* * *} \\
(0.725)\end{array}$ & $\begin{array}{c}2.622^{* * *} \\
(0.954)\end{array}$ & $\begin{array}{c}2.461^{* * *} \\
(0.780)\end{array}$ \\
\hline GDP_recipient(ln) & & & & $\begin{array}{c}0.068 \\
(0.696)\end{array}$ & & $\begin{array}{c}0.077 \\
(0.713)\end{array}$ \\
\hline GDPPC_recipient(ln) & $\begin{array}{c}0.213 \\
(0.255)\end{array}$ & $\begin{array}{c}2.502^{* * *} \\
(0.850)\end{array}$ & $\begin{array}{c}0.233 \\
(0.261)\end{array}$ & $\begin{array}{c}0.092 \\
(0.711)\end{array}$ & $\begin{array}{c}0.098 \\
(0.740)\end{array}$ & $\begin{array}{c}0.102 \\
(0.743)\end{array}$ \\
\hline $\ln ($ trade/gdp $)$ & $\begin{array}{l}-0.005 \\
(0.004)\end{array}$ & $\begin{array}{l}-0.005 \\
(0.004)\end{array}$ & $\begin{array}{l}-0.005 \\
(0.004)\end{array}$ & $\begin{array}{l}-0.005 \\
(0.004)\end{array}$ & $\begin{array}{l}-0.005 \\
(0.004)\end{array}$ & $\begin{array}{l}-0.005 \\
(0.004)\end{array}$ \\
\hline Democracy_freedom & $\begin{array}{c}0.028 \\
(0.023)\end{array}$ & $\begin{array}{c}0.017 \\
(0.023)\end{array}$ & $\begin{array}{c}0.029 \\
(0.024)\end{array}$ & $\begin{array}{c}0.017 \\
(0.025)\end{array}$ & $\begin{array}{c}0.017 \\
(0.025)\end{array}$ & $\begin{array}{c}0.017 \\
(0.024)\end{array}$ \\
\hline Investment treaty & $\begin{array}{c}0.283^{* *} \\
(0.124)\end{array}$ & $\begin{array}{c}0.316^{* * *} \\
(0.120)\end{array}$ & $\begin{array}{c}0.275^{* *} \\
(0.126)\end{array}$ & $\begin{array}{c}0.314^{* *} \\
(0.122)\end{array}$ & $\begin{array}{c}0.312^{* *} \\
(0.121)\end{array}$ & $\begin{array}{c}0.308^{* *} \\
(0.124)\end{array}$ \\
\hline Trade agreement & $\begin{array}{c}-0.003 \\
(0.192)\end{array}$ & $\begin{array}{c}0.044 \\
(0.195)\end{array}$ & $\begin{array}{c}0.003 \\
(0.197)\end{array}$ & $\begin{array}{c}0.044 \\
(0.189)\end{array}$ & $\begin{array}{c}0.040 \\
(0.195)\end{array}$ & $\begin{array}{c}0.037 \\
(0.192)\end{array}$ \\
\hline $\operatorname{DTA}(0)$ & $\begin{array}{c}0.340^{* *} \\
(0.140)\end{array}$ & $\begin{array}{c}0.358^{* *} \\
(0.146)\end{array}$ & $\begin{array}{c}0.250 \\
(0.413)\end{array}$ & $\begin{array}{c}0.356^{* *} \\
(0.143)\end{array}$ & $\begin{array}{c}0.357^{* *} \\
(0.145)\end{array}$ & $\begin{array}{c}0.401 \\
(0.397)\end{array}$ \\
\hline Bilateral FDI(ln) & $\begin{array}{c}0.002 \\
(0.007)\end{array}$ & & & $\begin{array}{l}-0.001 \\
(0.006)\end{array}$ & & \\
\hline $\operatorname{DTA}(0) * \mathrm{FDI}$ & $\begin{array}{c}0.019 \\
(0.012)\end{array}$ & & & $\begin{array}{l}0.021^{*} \\
(0.012)\end{array}$ & & \\
\hline GDP_ratio & & $\begin{array}{c}2.302^{* * *} \\
(0.837)\end{array}$ & & & $\begin{array}{c}-0.078 \\
(0.713)\end{array}$ & \\
\hline $\operatorname{DTA}(0) *$ GDP_ratio & & $\begin{array}{l}-0.037 \\
(0.034)\end{array}$ & & & $\begin{array}{c}-0.036 \\
(0.034)\end{array}$ & \\
\hline Corporate tax & & & $\begin{array}{c}0.608 \\
(1.141)\end{array}$ & & & $\begin{array}{c}0.403 \\
(1.153)\end{array}$ \\
\hline $\operatorname{DTA}(0)^{*}$ Corporate tax & & & $\begin{array}{c}-0.095 \\
(1.143)\end{array}$ & & & $\begin{array}{c}-0.461 \\
(1.116)\end{array}$ \\
\hline Observations & 6,941 & 7,006 & 7,006 & 6,941 & 7,006 & 7,006 \\
\hline Number of groups & 327 & 327 & 327 & 327 & 327 & 327 \\
\hline Wald chi2 & 198.86 & 221.51 & 208.53 & 224.19 & 217.22 & 220.09 \\
\hline p-value & 0.000 & 0.000 & 0.000 & 0.000 & 0.000 & 0.000 \\
\hline Pseudo Log-likelihood & $-72,220.38$ & $-71,746.30$ & $-72,630.27$ & $-71,770.78$ & $-71,349.15$ & $-71,771.23$ \\
\hline
\end{tabular}

Notes: Estimated with Poisson Maximum Likelihood Fixed Effects. The dependent variable is total bilateral ODA commitments; all explanatory variables are lagged by one period; all regressions include country-pair FE, year FE, and a constant; robust standard errors in parentheses; time period $1991-2012$; $^{* *} \mathrm{p}<0.01,{ }^{* *} \mathrm{p}<0.05,{ }^{*} \mathrm{p}<0.1$. 
tween the two countries are proxied by bilateral FDI stocks (Bilateral FDI $(\ln )$ ). In Column (1), where country size is proxied by population, the interaction effect is positive as predicted, but the p-value of the interaction variable lies slightly above conventional levels of statistical significance ( $p$-value of 0.105 ). When country size is measured by the two countries' GDPs, the interaction effect is positive and significant at the $10 \%$ level (see Column (4)). This suggests that the stronger the economic ties are between two countries, the more compensation the donor country is willing to pay for the signature of a DTA. Note that the DTA is only significant in the interaction term, implying that there is no level effect or lumpsum compensation, but compensation is only relative to the strength of economic ties.

The second hypothesis derived from the model is that the higher the relative bargaining power of the residence country, the lower the compensation for a DTA. The relative bargaining power is proxied by the ratio of the two countries' GDPs. The interaction effect between this GDP-ratio with the DTA variable indicates the impact of the relative bargaining power on ODA payments for a DTA (see Column (2) in Table 2). The coefficient has the expected negative sign, is however not statistically significant. Column (5) shows a similar regression, the only difference being that country size is measured by the two countries' GDPs rather than their populations (the recipient country's GDP is dropped in this column to avoid perfect collinearity). Also in this case, the interaction effects hints to a lower compensation in case of higher relative bargaining power of the donor country, even though the effect is again not statistically significant.

Finally, in Columns (3) and (6) - the difference between these two columns again being the different country size measures - we analyse the effect of the residence country's corporate income tax rate (Corporate tax) on the compensation payout. The model predicts no clear impact, and also the empirical regressions do not yield a clear result with the interaction effect between the Corporate tax and 
DTA variable being statistically insignificant 20

To sum up, the data supports Hypothesis 1. There is statistical evidence suggesting that ceteris paribus recipient countries with closer economic ties with the donor country tend to receive more foreign aid in exchange for a DTA. The data also do not outrightly contradict the second hypothesis, suggesting that the higher the relative bargaining power of a residence country, the lower is the price it is prepared to pay for a DTA. Hypothesis 3, i.e. an unclear effect of the residence country's reservation price, is reflected by the insignificant empirical results. Most importantly, all estimations are in line with our main prediction, i.e. that there is a price paid for the signature of a DTA.

\section{Robustness}

Finally, Table 8 shows additional regressions that include additional and alternative control variables to test whether the results depend on the covariates included. Firstly, to account for the fact that donors increase their aid to states that are affected by natural disasters, Columns (1) to (3) include the (logged) total number of persons affected by natural disasters (from the EM-DAT database). The variable Natural Catastrophe hence proxies the occurrence and strength of devastation of natural disasters. As humanitarian aid tends to be promised (and given) promptly without much time delay, the variable is not lagged by one period. Its coefficient is close to zero and not significant in our regressions, which may be due to the fact that humanitarian aid represents only a minor fraction of total aid Qian, 2015].

Secondly, we control for additional political factors that have been found to affect foreign aid. Empirical evidence suggests that bilateral aid is associated with the membership in the UN Security Council (UNSC) and the alignment in votes in the UN General Assembly Alesina and Dollar, 2000, Dreher et al., 2008, Kuziemko

${ }^{20}$ The signature of a DTA with a major capital exporter can be an important event for a capital importer, who may alter its corporate income tax rate, so that we cannot exclude an endogeneity bias in our estimation here 
and Werker, 2006]. To account for UNSC membership we construct the variable UNSCmembership as a binary variable that takes the value of 1 if two countries of a country-pair are simultaneously members of the UN Security Council (Table 5 in the Annex lists the cases). The variable is not statistically significant (see Columns (2) and (3) of Table 8). Also agreement in the UN General Assembly (UNGA_agreement) between the two countries of a country-pair turns out not to be associated with bilateral aid commitments in our regressions (see Column (3)).

Columns (4) to (7) of Table 8 then include alternative variables to account for the four P's: poverty, population, policies, and proximity. First, we use the (logged) life expectancy to account for the recipient country's poverty level (see Column (4) in Table 8). Akin to the recipient country's GDP per capita in most regressions, also this variable yields no statistically significant impact on ODA payments in our sample.

Second, we include the size of the donor and recipient countries as measured in terms of the (logged) GDP in constant USD. Both GDP_donor(ln) and GDP_recipient $(\ln )$ enter the regression with a positive sign and similar significance patterns as population, leaving the main results qualitatively unchanged (see Column (5) in Table 8).

Third, the institutional quality in the recipient country in accounted for with a different index. In Column (6) in Table 8, we take the index of democracy provided by the Center for Systemic Peace, which classifies countries from "strongly autocratic" to "strongly democratic" (Democracy_polity). As the democracy index used in the other regressions, this variable is not statistically significant at conventional levels.

Forth, Column 7 uses bilateral FDI stocks relative to the sum of the two countries' GDPs $(F D I / G D P(\ln ))$ instead of the bilateral relative trade volume as a measure of economic proximity. Similar to the bilateral relative trade volume, also the relative bilateral FDI stocks do not show a significant effect on ODA commitments. 
Most importantly, the main variable of interest, $D T A(0)$, remains positive and statistically significant at conventional levels in all regressions. The size of the effect varies around $22 \%$, with the relatively low effect of $18.6 \%$ (with a corresponding p-value of 0.066 ) in Column (3) probably due to the small sample size in this regression.

\section{Conclusions}

This paper has analyzed, both theoretically and empirically, the connection between bilateral foreign aid and double tax agreements. We theoretically claim that in asymmetric situations, where one country is predominantly a capital exporter and the other country a capital importer, a DTA is mutually beneficial if and only if there is compensation for the capital importer, that loses tax base, by the capital exporter. We claim that such a compensation can be given in the form of official development assistance. This need not be the sole form of compensation.

We have tested this hypothesis in a dyadic panel with fixed effects poisson regression analysis. We have found that recipient countries that sign a DTA with donor countries indeed receive about $22 \%$ more foreign aid in the signature year. We can also empirically confirm further predictions of the model.

This paper however can only analyze the patterns emerging from macro data and interpret them in a meaningful and convincing way, and thereby reach rather indirect conclusions about the connections between foreign aid and DTA conclusion. It would be insightful to have access to information that enables researchers to analyze how treaties are actually negotiated. At the moment, little is known about the actual negotiation process as DTAs are still mainly negotiated behind closed doors [e.g. Lang, 2012]. Likewise, there is limited information about aid allocation and bargaining processes between donor and recipient countries [e.g. Molenaers et al., 2015. 


\section{References}

ActionAid. Double tax treaties in uganda. impact and policy implications, July 2014. URL http://www.fairpolitics.nl/doc/DTT\%20In\%20Uganda\% 20Final\%2012_08_2014.pdf.

A. Alesina and D. Dollar. Who gives foreign aid to whom and why? Journal of

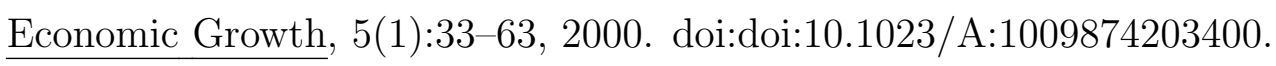

P. Baker. An analysis of double tax treaties and their effect on foreign direct investment. International Journal of the Economics and Business, 21(3):341377, 2014. doi:http://dx.doi.org/10.1080/13571516.2014.968454.

F. Barthel. Exploring spatial dependence in bi- and multilateral aid giving patterns. URL http://s3.amazonaws.com/aiddata/Barthel_aiddata.pdf.

B. Bittschi, S. Borgloh, and D. Moessinger. On tax evasion, entrepreneurial generosity and fungible assets. ZEW Discussion Paper No. 16-024, 2016. doi:http://dx.doi.org/10.2139/ssrn.2762301.

J. Braun and D. Fuentes. The effects of double tax treaties for developing countries. a case study of austria's doublte tax treaty network. Public Finance and Management, 16(4):383-433, 2016.

J. Braun and M. Zagler. An economic perspective on double tax treaties with(in) developing countries. World Tax Journal, 6(3):242-281, 2014.

E. Buergi and S. Meyer-Nandi. Schweizer doppelbesteuerungsabkommen: Aktuelle politik und entwicklungsrelevanz, 2013. URL http://www.alliancesud.ch/ de/ep/finanzen/downloads/DBAStudie20bei\%20WTI.pdf.

R. Chisik and R. B. Davies. Asymmetric fdi and tax-treaty bargaining: Theory and evidence. Journal of Public Economics, 88(6):1119-114, 2004. doi:http://dx.doi.org/10.1016/S0047-2727(03)00059-8. 
P. Clist. 25 years of aid allocation practice: Whither selectivity? $\quad$ World Development, 39(10):1724-1734, 2011. doi:http://dx.doi.org/10.1016/j.worlddev.2011.04.031.

T. Dagan. The tax treaty myth. N.Y.U. Journal of International Law and Politics, 32:939-996, 2000. doi:http://dx.doi.org/10.2139/ssrn.379181.

V. Daurer. Tax Treaties and Developing Countries. Wolters Kluwer, 2013.

B. Bueno de Mesquita and A. Smith. A political economy of foreign aid. International Organization, 63(2):309-340, 2009.

S. Dietrich. Bypass or engage? explaining donor delivery tactics in foreign aid allocation. International Studies Quarterly, 57:698-712, 2013. doi:10.1111/isqu.12041.

C. Dippel. Foreign aid and voting in international organizations: Evidence from the iwc. Journal of Public Economics, 132(C):1-12, 2015. doi:http://dx.doi.org/10.1016/j.jpubeco.2015.08.012.

A. Dreher, P. Nunnenkamp, and R. Thiele. Does us aid buy un general assembly votes? a disaggregated analysis. Public Choice, 136(1-2):139-64, 2008. doi: $10.1007 / \mathrm{s} 11127-008-9286-\mathrm{x}$.

A. Dreher, J.-E. Sturm, and J. Vreeland. Development aid and international politics: Does membership on the un security council influence world bank decisions? Journal of Development Economics, 88: 1-18, 2009a. doi:http://dx.doi.org/10.1016/j.jdeveco.2008.02.003. URL http://www.uni-heidelberg.de/fakultaeten/wiso/awi/professuren/ intwipol/datasets.html.

Axel Dreher, Jan-Egbert Sturm, and James Vreeland. Global horse trading: Imf loans for votes in the united nations secu- 
rity council. European Economic Review, 53(7):742-757, 2009b. doi:http://dx.doi.org/10.1016/j.euroecorev.2009.03.002.

Eurodad. Survival of the richest. europe's role in supporting unjust global tax systems 2016, 2016. URL http://eurodad.org/files/pdf/ 1546667-survival-of-the-richest.pdf.

M. Faye and P. Niehaus. Political aid cycles. American Economic Review, 102(7): 3516-3530, 2012. doi:http://dx.doi.org/10.1257/aer.102.7.3516.

E. Kersting and C. Kilby. With a little help from my friends: Global electioneering and world bank lending. Journal of Development Economics, 121(July):153-165, 2016. doi:http://dx.doi.org/10.1016/j.jdeveco.2016.03.010.

I. Kuziemko and E. Werker. How much is a seat on the security council worth? foreign aid and bribery at the united nations. Journal of Political Economy, 114 (5):905-930, 2006. doi:http://dx.doi.org/10.1086/507155.

M. Lang. Überlegungen zur österreichischen dba-politik. Steuer und Wirtschaft International, 22(3):108-127, 2012.

M. Lang and J. Owens. The role of tax treaties in faciliating development and protecting the tax base. WU International Taxation Research Paper Series No. 2014-03, 2014. URL http://epub.wu . ac.at/4094/1/SSRN-id2398438.pdf.

J. Ligthart, M. Vlachaki, and J. Voget. The determinants of double tax treaty formation. mimeo, 2012.

K. McGauran. Should the Netherlands Sign Tax Treaties with Developing Countries? SOMO, 2013. URL http://www.eurodad.org/files/ integration/2013/06/DTA-report-final1.pdf.

Nadia Molenaers, Sebastian Dellepiane, and Jorg Faust. Political conditionality and foreign aid. World Development, 75:2-12, 2015. doi:http://dx.doi.org/10.1016/j.worlddev.2015.04.001. 
OECD. Global Forum on Transparency and Exchange of Information for Tax Purposes Peer Reviews: Philippines 2013: Phase 2: Implementation of the Standard in Practice. OECD Publishing, 2013. doi:10.1787/9789264206236-en.

OECD. Global Forum on Transparency and Exchange of Information for Tax Purposes Peer Reviews: Malaysia 2014: Phase 2: Implementation of the

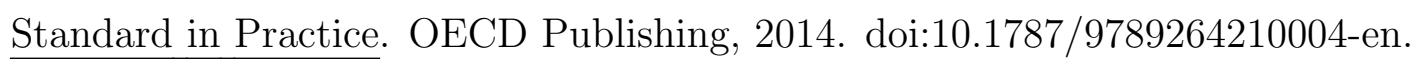

D. Paolini, P. Pistone, G. Pulina, and M. Zagler. Tax treaties with developing countries and the allocation of taxing rights. European Journal of Law and Economics, 39(1):99-199, 2015. doi:10.1007/s10657-014-9465-9.

A. Pickering. Why negotiate tax treaties? Papers on Selected Topics in Negotiation of Tax Treaties for Developing Countries, Paper 1-N. New York and Geneva: United Nations., 2013.

N. Qian. Making progress on foreign aid. Annual Review of Economics, 7:277-308, 2015. doi:10.1146/annurev-economics-080614-115553.

T. Rixen and P. Schwarz. Bargaining over the avoidance of double taxation: Evidence from german tax treaties. Finanzarchiv/Public Finance Analysis, 65 (4):442-471, 2009. doi:http://dx.doi.org/10.2139/ssrn.2502529.

A. Rubinstein. Perfect equilibrium in a bragaining model. Econometrica, 50(1): 97-109, 1982. doi:10.2307/1912531.

J. Silva and S. Tenreyro. The log of gravity. The Review of Economics and Statistics, 88(4):641-658, 2006.

J. Silva and S. Tenreyro. Further simulation evidence on the performance of hte poisson pseudo-maximum likelihood estimator. Economics Letters, 112(2):220222, 2011. doi:http://dx.doi.org/10.1016/j.econlet.2011.05.008.

A. Streshnev and E. Voeten. United nations general assembly voting data, 2013. 
V. Thuronyi. Tax Treaties: Building Bridges between Law and Economics, chapter Tax Treaties and Developing Countries, pages 441-455. IBFD, Amsterdam, 2010.

W. Wijnen and J. de Goede. The un model in practice 1997-2013. Bulletin for International Taxation, 3:118-146, 2014.

\section{Annex}


Table 3: DAC Member Countries as of 2012

\begin{tabular}{ccc}
\hline \hline Australia & Greece & Norway \\
Austria & Ireland & Portugal \\
Belgium & Italy & Spain \\
Canada & Japan & Sweden \\
Denmark & Rep. of Korea & Switzerland \\
Finland & Luxembourg & United Kingdom \\
France & The Netherlands & United States \\
Germany & New Zealand & \\
\hline \hline
\end{tabular}

Notes: Even though a DAC member since 1961, the European Union is disregarded as a donor in our analysis. Czech Republic, Iceland, Poland, Slovak Republic, and Slovenia joined the DAC in 2013.

source: www.oecd.org/dac

Table 4: Recipient countries included in the analysis

\begin{tabular}{ccc}
\hline \hline Albania (12) & Guinea (1) & Nepal (3) \\
Algeria (9) & Guyana (1) & Nigeria (2) \\
Argentina (11) & India (9) & Pakistan (4) \\
Armenia (9) & Indonesia (4) & Panama (4) \\
Azerbaijan (10) & Iran (4) & Papua New Guinea (3) \\
Bangladesh (5) & Jordan (5) & Peru (2) \\
Belarus (6) & Kazakhstan (9) & Rwippines (2) \\
Belize (1) & Kenya (1) & Senegal (3) \\
Bolivia (5) & Kiribati (1) & Serbia (6) \\
Bosnia and Herzegovina (2) & Kyrgyz Republic (5) & South Africa (19) \\
Botswana (3) & Lao PDR (2) & Tajikistan (2) \\
Brazil (1) & Lebanon (1) & Tanzania (1) \\
China (5) & Lesotho (1) & Thailand (7) \\
Colombia (4) & Libya (2) & Tunisia (5) \\
Cuba (2) & Macedonia, FYR (9) & Uganda (3) \\
Ecuador (5) & Malawi (1) & Ukraine (11) \\
Egypt (5) & Malaysia (3) & Uzbekistan (10) \\
El Salvador (1) & Mauritius (3) & Venezuela (13) \\
Ethiopia(3) & Moldova (5) & Vietnam (18) \\
Rep Fiji (1) & Mongolia (10) & Zimbabwe (2) \\
Gabon (3) & Montenegro (1) $(1)$ & \\
Gambia (2) & Morocco (4) & \\
Georgia (8) & Mozambique (1) & \\
Ghana (6) & Namibia (3) & \\
\hline \hline
\end{tabular}

Notes: Number in brackets shows number of DTAs signed and included in the analysis.

Source: www.oecd.org/dac, IBFD Tax Research Platform 
Table 5: Both countries concurrently members of the UN Security Council

\begin{tabular}{cc}
\hline \hline France-Algeria 2004\&2005 & France-Vietnam 2008\&2009 \\
France-Azerbaijan 2012 & France-Zimbabwe 1991\&1992 \\
France-Botswana 1995\&1996 & U.K.-Argentina 1994\&1995, 1999\&2000, 2005\&2006, 2012 \\
France-Gabon 1998\&1999, 2010\&2011 & U.K.-Botswana 1995\&1996 \\
France-Ghana 2006\&2007 & U.K.-Ghana 2006\&2007 \\
France-Guinea 2002\&2003 & U.K.-India 1991\&1992, 2011\&2012 \\
France-India 1991\&1992, 2002\&2006 & U.K.-Libya 2008\&2009 \\
France-Jamaica 2000\&2001 & U.K.-South Africa 2007\&2008, 2011\&2012 \\
France-Kenya 1997\&1998 & U.K.-Uganda 2009\&2010 \\
France-Libya 2008\&2009 & U.K.-Ukraine 2000\&2001 \\
France-Namibia 1999\&2000 & U.K.-Venezuela, RB 1992\&1993 \\
France-Panama 2007\&2008 & U.K.-Vietnam 2008\&2009 \\
France-South Africa 2007\&2008, 2011\&2012 & U.S.-South Africa 2007\&2008, 2011\&2012 \\
France-Syrian Arab Republic 2002\&2003 & U.S.-Ukraine 2000\&2001 \\
France-Venezuela, RB 1992\&1993 & U.S.-Venezuela, RB 1992\&1993 \\
\hline \hline
\end{tabular}

Source: Dreher et al. $[2009 \mathrm{a}$

Table 6: Summary statistics

\begin{tabular}{lccccc}
\hline \hline \multicolumn{1}{c}{ Variable } & Mean & Std. Dev. & Min. & Max. & N \\
\hline Total ODA commitment & 27.365 & 98.862 & 0 & 4284.81 & 7006 \\
POP_donor(ln) & 16.653 & 1.326 & 12.866 & 19.565 & 7006 \\
POP_recipient(ln) & 16.679 & 1.616 & 11.189 & 21.024 & 7006 \\
GDP_donor(ln) & 27.047 & 1.152 & 23.685 & 30.259 & 7006 \\
GDP_recipient(ln) & 23.989 & 1.72 & 17.985 & 29.065 & 7006 \\
GDPPC_recipient(ln) & 7.322 & 0.941 & 4.717 & 9.116 & 7006 \\
LifeExpectancy_recipient(ln) & 4.198 & 0.116 & 3.299 & 4.37 & 7013 \\
Democracy_freedom & 7.771 & 3.251 & 2 & 14 & 7006 \\
Democracy_polity & 2.123 & 6.451 & -9 & 10 & 6920 \\
Bilateral Trade(ln) & -23.054 & 15.426 & -44.096 & -3.508 & 7006 \\
Bilateral FDI(ln) & -7.469 & 8.73 & -13.816 & 10.662 & 6941 \\
Corporate tax & 0.331 & 0.067 & 0.2 & 0.58 & 7006 \\
Natural Catastrophe & 7.386 & 5.886 & 0 & 19.65 & 7006 \\
UNSC_membership & 0.01 & 0.102 & 0 & 1 & 7006 \\
UNGA_agreement & 0.74 & 0.119 & 0.104 & 1 & 6384 \\
Investment treaty & 0.597 & 0.49 & 0 & 1 & 7006 \\
Trade agreement & 0.114 & 0.318 & 0 & 1 & 7006 \\
DTA & 0.605 & 0.489 & 0 & 1 & 7006 \\
DTA(0) & 0.047 & 0.211 & 0 & 1 & 7006 \\
\hline \hline
\end{tabular}


Table 7: Variable Description

\begin{tabular}{|c|c|c|}
\hline ODA commitments & $\begin{array}{l}\text { Total Bilateral Official Development } \\
\text { Assistance commitments in constant } \\
2014 \text { USD }\end{array}$ & $\begin{array}{l}\text { OECD International Development } \\
\text { Statistics, DAC database }\end{array}$ \\
\hline DTA & $\begin{array}{l}\text { Binary variable taking the value } 1 \text { in } \\
\text { the year of the signature of a Double } \\
\text { Tax Agreeement }\end{array}$ & IBFD Tax Research Platform \\
\hline POP_donor(ln) & logged population of the donor country & $\begin{array}{l}\text { World Bank World Development Indi- } \\
\text { cators }\end{array}$ \\
\hline POP_recipient(ln) & $\begin{array}{l}\text { logged population of the recipient } \\
\text { country }\end{array}$ & $\begin{array}{l}\text { World Bank World Development Indi- } \\
\text { cators }\end{array}$ \\
\hline GDP_donor(ln) & $\begin{array}{l}\text { logged GDP of the donor country in } \\
\text { const } 2005 \text { USD }\end{array}$ & $\begin{array}{l}\text { World Bank World Development Indi- } \\
\text { cators }\end{array}$ \\
\hline GDP_recipient(ln) & $\begin{array}{l}\text { logged GDP of the recipient country in } \\
\text { const } 2005 \text { USD }\end{array}$ & $\begin{array}{l}\text { World Bank World Development Indi- } \\
\text { cators }\end{array}$ \\
\hline GDPPC_recipient(ln) & $\begin{array}{l}\text { logged GDP per capita of the recipient } \\
\text { country in const } 2005 \text { USD }\end{array}$ & $\begin{array}{l}\text { World Bank World Development Indi- } \\
\text { cators }\end{array}$ \\
\hline Bilateral FDI (ln) & $\begin{array}{l}\text { Bilateral FDI stock between the two } \\
\text { countries of a country-pair in constant } \\
2015 \text { USD (converted from current } \\
\text { USD to constant USD with US GDP } \\
\text { deflator(taken from WDI database)) }\end{array}$ & $\begin{array}{l}\text { OECD Foreign Direct Investment } \\
\text { Statistics }\end{array}$ \\
\hline Bilateral Trade(ln) & $\begin{array}{l}\text { Bilateral trade volume between two } \\
\text { countries in constant } 2015 \text { USD (con- } \\
\text { verted from current USD to constant } \\
\text { USD with US GDP deflator(taken from } \\
\text { WDI database)) } i \text { and } j\end{array}$ & $\begin{array}{l}\text { United Nations International Trade } \\
\text { Statistics (UN COMTRADE) }\end{array}$ \\
\hline \multirow[t]{2}{*}{ Democracy_freedom } & \multirow{2}{*}{$\begin{array}{l}\text { Inverted sum of the civil liberty index } \\
\text { and the political rights index in the re- } \\
\text { cipient country, ranging from } 0 \text { to } 15, \\
\text { with higher values referring to higher } \\
\text { levels of democracy }\end{array}$} & https://www. \\
\hline & & $\begin{array}{l}\text { freedomhouse.org/report-types/ } \\
\text { freedom-world }\end{array}$ \\
\hline Democracy_polity & $\begin{array}{l}\text { Measure of democracy in the recipient } \\
\text { country, ranging from }-10 \text { (strongly au- } \\
\text { tocratic) to }+10 \text { (strongly democratic) }\end{array}$ & $\begin{array}{l}\text { Polity IV dataset version } 2015 \\
\text { ip4v2015 and p4v2015d }\end{array}$ \\
\hline UNGA_agreement & $\begin{array}{l}\text { Index measuring agreement in UN } \\
\text { General Assembly votes }\end{array}$ & Streshnev and Voeten 2013 \\
\hline UNSC membership & $\begin{array}{l}\text { binary variable taking the value } 1 \text { if } \\
\text { both countries of a country-pair are } \\
\text { concurrently members of the UN Secu- } \\
\text { rity Council }\end{array}$ & Dreher et al. 2009 \\
\hline Natural Catastrophe & $\begin{array}{l}\text { (logged) total number of persons af- } \\
\text { fected by a natural catastrophe (sum } \\
\text { of injured, homeless, and affected per- } \\
\text { sons) }\end{array}$ & $\begin{array}{l}\text { EM-DAT database http://www. emdat. } \\
\text { be/ }\end{array}$ \\
\hline Life Expectancy_recipient & $\begin{array}{l}\text { Life expectancy at birth, total years } \\
\text { (logged), in the recipient country }\end{array}$ & $\begin{array}{l}\text { World Bank, World Development Indi- } \\
\text { cators }\end{array}$ \\
\hline Corporate tax & Tax Rate on Corporate Profits & IBFD Tax Research Platform \\
\hline \multirow[t]{2}{*}{ Investment treaty } & \multirow{2}{*}{$\begin{array}{l}\text { Binary variable taking the value } 1 \text { in } \\
\text { the year of the signature of a Bilateral } \\
\text { Investment Treaty }\end{array}$} & UNCTAD United Nations http: \\
\hline & & $\begin{array}{l}\text { //inves } \\
\text { IIA }\end{array}$ \\
\hline \multirow[t]{4}{*}{ Trade agreement } & \multirow{4}{*}{$\begin{array}{l}\text { Binary variable taking the value } 1 \text { in } \\
\text { the year of the signature of a Preferen- } \\
\text { tial Trade Agreement }\end{array}$} & World Trade Organization https: \\
\hline & & //www.wto.org/english/tratop_e/ \\
\hline & & region_e/rta_participation_map_e. \\
\hline & & $\mathrm{htm}$ \\
\hline
\end{tabular}


Table 8: Robustness Regression Results 1

\begin{tabular}{|c|c|c|c|c|c|c|c|}
\hline VARIABLES & 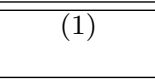 & $\overline{(2)}$ & 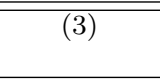 & $\overline{(4)}$ & $\overline{(5)}$ & $\overline{(26)}$ & 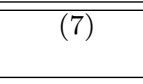 \\
\hline POP_donor(ln) & $\begin{array}{c}5.094^{* *} \\
(2.116)\end{array}$ & $\begin{array}{c}5.001 * * \\
(2.072)\end{array}$ & $\begin{array}{c}5.050 * * \\
(1.996)\end{array}$ & $\begin{array}{l}4.587^{* *} \\
(2.178)\end{array}$ & & $\begin{array}{c}5.796^{* * *} \\
(2.110)\end{array}$ & $\begin{array}{l}4.692^{* *} \\
(2.048)\end{array}$ \\
\hline POP_recipient(ln) & $\begin{array}{c}0.159 \\
(0.741)\end{array}$ & $\begin{array}{c}0.110 \\
(0.743)\end{array}$ & $\begin{array}{c}0.417 \\
(0.740)\end{array}$ & $\begin{array}{c}0.215 \\
(0.828)\end{array}$ & & $\begin{array}{c}0.089 \\
(0.741)\end{array}$ & $\begin{array}{c}0.070 \\
(0.725)\end{array}$ \\
\hline GDPPC_recipient(ln) & $\begin{array}{c}0.236 \\
(0.262)\end{array}$ & $\begin{array}{c}0.240 \\
(0.258)\end{array}$ & $\begin{array}{l}0.459^{*} \\
(0.268)\end{array}$ & & $\begin{array}{c}0.102 \\
(0.730)\end{array}$ & $\begin{array}{c}0.323 \\
(0.252)\end{array}$ & $\begin{array}{c}0.217 \\
(0.285)\end{array}$ \\
\hline Bilateral trade $(\ln )$ & $\begin{array}{l}-0.005 \\
(0.004)\end{array}$ & $\begin{array}{l}-0.005 \\
(0.004)\end{array}$ & $\begin{array}{l}-0.005 \\
(0.004)\end{array}$ & $\begin{array}{l}-0.005 \\
(0.004)\end{array}$ & $\begin{array}{l}-0.005 \\
(0.004)\end{array}$ & $\begin{array}{l}-0.004 \\
(0.003)\end{array}$ & \\
\hline Democracy_freedom & $\begin{array}{c}0.029 \\
(0.024)\end{array}$ & $\begin{array}{c}0.029 \\
(0.024)\end{array}$ & $\begin{array}{c}0.012 \\
(0.028)\end{array}$ & $\begin{array}{c}0.031 \\
(0.025)\end{array}$ & $\begin{array}{c}0.017 \\
(0.025)\end{array}$ & & $\begin{array}{c}0.030 \\
(0.025)\end{array}$ \\
\hline Investment treaty & $\begin{array}{c}0.279 * * \\
(0.122)\end{array}$ & $\begin{array}{c}0.284^{* *} \\
(0.122)\end{array}$ & $\begin{array}{c}0.293^{* *} \\
(0.127)\end{array}$ & $\begin{array}{c}0.306^{* * *} \\
(0.118)\end{array}$ & $\begin{array}{c}0.310^{* *} \\
(0.121)\end{array}$ & $\begin{array}{c}0.298^{* *} \\
(0.127)\end{array}$ & $\begin{array}{c}0.322^{* * *} \\
(0.113)\end{array}$ \\
\hline Trade agreement & $\begin{array}{c}0.008 \\
(0.203)\end{array}$ & $\begin{array}{c}0.009 \\
(0.203)\end{array}$ & $\begin{array}{c}0.037 \\
(0.201)\end{array}$ & $\begin{array}{l}-0.021 \\
(0.206)\end{array}$ & $\begin{array}{c}0.041 \\
(0.196)\end{array}$ & $\begin{array}{c}0.059 \\
(0.205)\end{array}$ & $\begin{array}{c}0.008 \\
(0.188)\end{array}$ \\
\hline $\operatorname{DTA}(-3)$ & $\begin{array}{c}0.022 \\
(0.142)\end{array}$ & $\begin{array}{c}0.027 \\
(0.142)\end{array}$ & $\begin{array}{l}-0.023 \\
(0.149)\end{array}$ & $\begin{array}{c}0.021 \\
(0.143)\end{array}$ & $\begin{array}{c}0.009 \\
(0.137)\end{array}$ & $\begin{array}{c}0.046 \\
(0.150)\end{array}$ & $\begin{array}{c}0.026 \\
(0.143)\end{array}$ \\
\hline $\operatorname{DTA}(-2)$ & $\begin{array}{l}-0.138 \\
(0.145)\end{array}$ & $\begin{array}{l}-0.142 \\
(0.145)\end{array}$ & $\begin{array}{l}-0.171 \\
(0.153)\end{array}$ & $\begin{array}{l}-0.139 \\
(0.147)\end{array}$ & $\begin{array}{l}-0.141 \\
(0.148)\end{array}$ & $\begin{array}{l}-0.130 \\
(0.150)\end{array}$ & $\begin{array}{l}-0.163 \\
(0.161)\end{array}$ \\
\hline $\operatorname{DTA}(-1)$ & $\begin{array}{l}-0.032 \\
(0.124)\end{array}$ & $\begin{array}{l}-0.034 \\
(0.125)\end{array}$ & $\begin{array}{l}-0.060 \\
(0.131)\end{array}$ & $\begin{array}{l}-0.034 \\
(0.129)\end{array}$ & $\begin{array}{l}-0.027 \\
(0.121)\end{array}$ & $\begin{array}{l}-0.017 \\
(0.138)\end{array}$ & $\begin{array}{l}-0.017 \\
(0.130)\end{array}$ \\
\hline $\operatorname{DTA}(0)$ & $\begin{array}{c}0.218^{* *} \\
(0.092)\end{array}$ & $\begin{array}{c}0.224^{* *} \\
(0.091)\end{array}$ & $\begin{array}{l}0.189^{*} \\
(0.100)\end{array}$ & $\begin{array}{c}0.217^{* *} \\
(0.095)\end{array}$ & $\begin{array}{c}0.229^{* *} \\
(0.094)\end{array}$ & $\begin{array}{c}0.233^{* *} \\
(0.091)\end{array}$ & $\begin{array}{l}0.127^{*} \\
(0.072)\end{array}$ \\
\hline $\operatorname{DTA}(+1)$ & $\begin{array}{c}0.064 \\
(0.119)\end{array}$ & $\begin{array}{c}0.070 \\
(0.118)\end{array}$ & $\begin{array}{c}0.049 \\
(0.123)\end{array}$ & $\begin{array}{c}0.058 \\
(0.125)\end{array}$ & $\begin{array}{c}0.075 \\
(0.123)\end{array}$ & $\begin{array}{c}0.095 \\
(0.118)\end{array}$ & $\begin{array}{c}0.067 \\
(0.118)\end{array}$ \\
\hline $\mathrm{DTA}(+2)$ & $\begin{array}{c}0.022 \\
(0.077)\end{array}$ & $\begin{array}{c}0.028 \\
(0.076)\end{array}$ & $\begin{array}{c}0.007 \\
(0.075)\end{array}$ & $\begin{array}{c}0.017 \\
(0.074)\end{array}$ & $\begin{array}{c}0.034 \\
(0.072)\end{array}$ & $\begin{array}{c}0.045 \\
(0.074)\end{array}$ & $\begin{array}{c}0.065 \\
(0.069)\end{array}$ \\
\hline $\operatorname{DTA}(+3)$ & $\begin{array}{c}0.131 \\
(0.089)\end{array}$ & $\begin{array}{c}0.133 \\
(0.089)\end{array}$ & $\begin{array}{c}0.112 \\
(0.091)\end{array}$ & $\begin{array}{c}0.121 \\
(0.090)\end{array}$ & $\begin{array}{c}0.134 \\
(0.092)\end{array}$ & $\begin{array}{l}0.154^{*} \\
(0.086)\end{array}$ & $\begin{array}{c}0.138 \\
(0.091)\end{array}$ \\
\hline Natural Catastrophe & $\begin{array}{c}0.003 \\
(0.006)\end{array}$ & $\begin{array}{c}0.003 \\
(0.006)\end{array}$ & $\begin{array}{c}0.003 \\
(0.006)\end{array}$ & & & & \\
\hline UNSC Membership & & $\begin{array}{c}0.241 \\
(0.186)\end{array}$ & $\begin{array}{c}0.204 \\
(0.179)\end{array}$ & & & & \\
\hline UNGA Agreement & & & $\begin{array}{l}-0.479 \\
(0.565)\end{array}$ & & & & \\
\hline LifeExpectancy_recipient(ln) & & & & $\begin{array}{l}-0.703 \\
(1.012)\end{array}$ & & & \\
\hline GDP_donor(ln) & & & & & $\begin{array}{c}2.536^{* * *} \\
(0.722)\end{array}$ & & \\
\hline GDP_recipient(ln) & & & & & $\begin{array}{c}0.074 \\
(0.705)\end{array}$ & & \\
\hline Democracy_polity & & & & & & $\begin{array}{l}-0.007 \\
(0.014)\end{array}$ & \\
\hline $\ln (\mathrm{fdi} / \mathrm{gdp})$ & & & & & & & $\begin{array}{l}-0.002 \\
(0.003)\end{array}$ \\
\hline Observations & 7,006 & 7,006 & 6,384 & 7,013 & 7,006 & 6,920 & 6,614 \\
\hline Number of groups & 327 & 327 & 320 & 327 & 327 & 323 & 327 \\
\hline Wald chi2 & 247.47 & 253.68 & 231.47 & 230.86 & 261.21 & 235.80 & 248.26 \\
\hline p-value & 0.000 & 0.000 & 0.000 & 0.000 & 0.000 & 0.000 & 0.000 \\
\hline Pseudo Log-likelihood & $-72,510.19$ & $-72,344.41$ & $-66,968.64$ & $-71,834.57$ & $-71,636.62$ & $-71,467.04$ & $-69,854.63$ \\
\hline
\end{tabular}


Table 9: Robustness Regression Results 2: Exclusion of Greece and Korea

\begin{tabular}{|c|c|c|c|c|c|c|c|}
\hline VARIABLES & 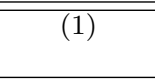 & $\overline{(2)}$ & 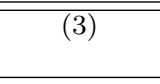 & $\overline{(4)}$ & $\overline{(5)}$ & $\overline{(26)}$ & 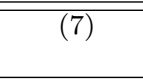 \\
\hline POP_donor(ln) & $\begin{array}{c}4.936^{* *} \\
(2.151)\end{array}$ & $\begin{array}{c}4.839^{* *} \\
(2.107)\end{array}$ & $\begin{array}{c}5.120^{* *} \\
(2.026)\end{array}$ & $\begin{array}{l}4.464^{* *} \\
(2.224)\end{array}$ & & $\begin{array}{c}5.663^{* * *} \\
(2.139)\end{array}$ & $\begin{array}{c}4.565^{* *} \\
(2.096)\end{array}$ \\
\hline POP_recipient(ln) & $\begin{array}{c}0.312 \\
(0.722)\end{array}$ & $\begin{array}{c}0.262 \\
(0.726)\end{array}$ & $\begin{array}{c}0.574 \\
(0.726)\end{array}$ & $\begin{array}{c}0.388 \\
(0.808)\end{array}$ & & $\begin{array}{c}0.268 \\
(0.717)\end{array}$ & $\begin{array}{c}0.217 \\
(0.712)\end{array}$ \\
\hline GDPPC_recipient(ln) & $\begin{array}{c}0.217 \\
(0.277)\end{array}$ & $\begin{array}{c}0.220 \\
(0.273)\end{array}$ & $\begin{array}{c}0.442 \\
(0.282)\end{array}$ & & $\begin{array}{c}0.017 \\
(0.729)\end{array}$ & $\begin{array}{c}0.308 \\
(0.265)\end{array}$ & $\begin{array}{c}0.190 \\
(0.302)\end{array}$ \\
\hline Bilateral trade $(\ln )$ & $\begin{array}{l}-0.004 \\
(0.004)\end{array}$ & $\begin{array}{l}-0.004 \\
(0.004)\end{array}$ & $\begin{array}{l}-0.004 \\
(0.004)\end{array}$ & $\begin{array}{l}-0.004 \\
(0.004)\end{array}$ & $\begin{array}{l}-0.004 \\
(0.004)\end{array}$ & $\begin{array}{l}-0.003 \\
(0.003)\end{array}$ & \\
\hline Democracy_freedom & $\begin{array}{c}0.028 \\
(0.025)\end{array}$ & $\begin{array}{c}0.029 \\
(0.025)\end{array}$ & $\begin{array}{c}0.011 \\
(0.028)\end{array}$ & $\begin{array}{c}0.031 \\
(0.025)\end{array}$ & $\begin{array}{c}0.021 \\
(0.026)\end{array}$ & & $\begin{array}{c}0.031 \\
(0.025)\end{array}$ \\
\hline Investment treaty & $\begin{array}{c}0.297^{* *} \\
(0.122)\end{array}$ & $\begin{array}{c}0.302^{* *} \\
(0.123)\end{array}$ & $\begin{array}{c}0.323^{* *} \\
(0.127)\end{array}$ & $\begin{array}{c}0.325^{* * *} \\
(0.119)\end{array}$ & $\begin{array}{c}0.306^{* *} \\
(0.126)\end{array}$ & $\begin{array}{c}0.315^{* *} \\
(0.129)\end{array}$ & $\begin{array}{c}0.335^{* * *} \\
(0.114)\end{array}$ \\
\hline Trade agreement & $\begin{array}{c}0.043 \\
(0.206)\end{array}$ & $\begin{array}{c}0.044 \\
(0.206)\end{array}$ & $\begin{array}{c}0.064 \\
(0.205)\end{array}$ & $\begin{array}{c}0.015 \\
(0.208)\end{array}$ & $\begin{array}{c}0.043 \\
(0.197)\end{array}$ & $\begin{array}{c}0.094 \\
(0.209)\end{array}$ & $\begin{array}{c}0.051 \\
(0.189)\end{array}$ \\
\hline $\operatorname{DTA}(-3)$ & $\begin{array}{c}0.029 \\
(0.146)\end{array}$ & $\begin{array}{c}0.034 \\
(0.146)\end{array}$ & $\begin{array}{l}-0.036 \\
(0.153)\end{array}$ & $\begin{array}{c}0.029 \\
(0.147)\end{array}$ & $\begin{array}{c}0.017 \\
(0.141)\end{array}$ & $\begin{array}{c}0.053 \\
(0.153)\end{array}$ & $\begin{array}{c}0.034 \\
(0.148)\end{array}$ \\
\hline $\operatorname{DTA}(-2)$ & $\begin{array}{l}-0.143 \\
(0.148)\end{array}$ & $\begin{array}{l}-0.149 \\
(0.148)\end{array}$ & $\begin{array}{l}-0.179 \\
(0.156)\end{array}$ & $\begin{array}{l}-0.146 \\
(0.150)\end{array}$ & $\begin{array}{l}-0.145 \\
(0.151)\end{array}$ & $\begin{array}{l}-0.136 \\
(0.154)\end{array}$ & $\begin{array}{l}-0.167 \\
(0.165)\end{array}$ \\
\hline $\operatorname{DTA}(-1)$ & $\begin{array}{l}-0.032 \\
(0.122)\end{array}$ & $\begin{array}{l}-0.035 \\
(0.123)\end{array}$ & $\begin{array}{l}-0.066 \\
(0.129)\end{array}$ & $\begin{array}{l}-0.034 \\
(0.127)\end{array}$ & $\begin{array}{l}-0.030 \\
(0.120)\end{array}$ & $\begin{array}{l}-0.017 \\
(0.135)\end{array}$ & $\begin{array}{l}-0.012 \\
(0.127)\end{array}$ \\
\hline $\operatorname{DTA}(0)$ & $\begin{array}{c}0.217^{* *} \\
(0.093)\end{array}$ & $\begin{array}{c}0.224^{* *} \\
(0.092)\end{array}$ & $\begin{array}{l}0.186^{*} \\
(0.101)\end{array}$ & $\begin{array}{c}0.216^{* *} \\
(0.097)\end{array}$ & $\begin{array}{c}0.227^{* *} \\
(0.096)\end{array}$ & $\begin{array}{c}0.233^{* *} \\
(0.093)\end{array}$ & $\begin{array}{l}0.127^{*} \\
(0.072)\end{array}$ \\
\hline $\operatorname{DTA}(+1)$ & $\begin{array}{c}0.053 \\
(0.121)\end{array}$ & $\begin{array}{c}0.060 \\
(0.120)\end{array}$ & $\begin{array}{c}0.034 \\
(0.124)\end{array}$ & $\begin{array}{c}0.048 \\
(0.126)\end{array}$ & $\begin{array}{c}0.060 \\
(0.127)\end{array}$ & $\begin{array}{c}0.085 \\
(0.120)\end{array}$ & $\begin{array}{c}0.054 \\
(0.120)\end{array}$ \\
\hline $\mathrm{DTA}(+2)$ & $\begin{array}{c}0.014 \\
(0.077)\end{array}$ & $\begin{array}{c}0.020 \\
(0.076)\end{array}$ & $\begin{array}{c}0.004 \\
(0.075)\end{array}$ & $\begin{array}{c}0.017 \\
(0.074)\end{array}$ & $\begin{array}{c}0.022 \\
(0.073)\end{array}$ & $\begin{array}{c}0.040 \\
(0.075)\end{array}$ & $\begin{array}{c}0.061 \\
(0.070)\end{array}$ \\
\hline $\operatorname{DTA}(+3)$ & $\begin{array}{c}0.117 \\
(0.092)\end{array}$ & $\begin{array}{c}0.119 \\
(0.092)\end{array}$ & $\begin{array}{c}0.108 \\
(0.094)\end{array}$ & $\begin{array}{c}0.117 \\
(0.093)\end{array}$ & $\begin{array}{c}0.118 \\
(0.094)\end{array}$ & $\begin{array}{c}0.142 \\
(0.089)\end{array}$ & $\begin{array}{c}0.127 \\
(0.094)\end{array}$ \\
\hline Natural Catastrophe & $\begin{array}{c}0.004 \\
(0.007)\end{array}$ & $\begin{array}{c}0.004 \\
(0.007)\end{array}$ & $\begin{array}{c}0.005 \\
(0.007)\end{array}$ & & & & \\
\hline UNSC Membership & & $\begin{array}{c}0.253 \\
(0.185)\end{array}$ & $\begin{array}{c}0.218 \\
(0.178)\end{array}$ & & & & \\
\hline UNGA Agreement & & & $\begin{array}{l}-0.312 \\
(0.602)\end{array}$ & & & & \\
\hline LifeExpectancy_recipient(ln) & & & & $\begin{array}{l}-0.685 \\
(1.039)\end{array}$ & & & \\
\hline GDP_donor(ln) & & & & & $\begin{array}{c}2.097^{* * *} \\
(0.810)\end{array}$ & & \\
\hline GDP_recipient(ln) & & & & & $\begin{array}{c}0.153 \\
(0.699)\end{array}$ & & \\
\hline Democracy_polity & & & & & & $\begin{array}{l}-0.008 \\
(0.014)\end{array}$ & \\
\hline $\ln (\mathrm{fdi} / \mathrm{gdp})$ & & & & & & & $\begin{array}{l}-0.002 \\
(0.003)\end{array}$ \\
\hline Observations & 6,182 & 6,182 & 5,621 & 6,197 & 6,182 & 6,096 & 5,862 \\
\hline Number of groups & 289 & 289 & 283 & 289 & 289 & 285 & 289 \\
\hline Wald chi2 & 234.96 & 236.50 & 222.86 & 221.44 & 240.99 & 226.77 & 236.92 \\
\hline p-value & 0.000 & 0.000 & 0.000 & 0.000 & 0.000 & 0.000 & 0.000 \\
\hline Pseudo Log-likelihood & $-67,073.88$ & $-66,891.45$ & $-62,099.56$ & $-66,534.48$ & $-67,062.91$ & $-66,041.74$ & $-64,603.68$ \\
\hline
\end{tabular}

